\title{
Carbonate saturation state of surface waters in the Ross Sea and Southern Ocean: controls and implications for the onset of aragonite undersaturation
}

\author{
H. B. DeJong, R. B. Dunbar, D. Mucciarone, and D. A. Koweek \\ Department of Earth System Science, Stanford University, Stanford, CA, USA \\ Correspondence to: H. B. DeJong (hdejong@stanford.edu) \\ Received: 6 May 2015 - Published in Biogeosciences Discuss.: 8 June 2015 \\ Revised: 30 October 2015 - Accepted: 23 November 2015 - Published: 2 December 2015
}

\begin{abstract}
Predicting when surface waters of the Ross Sea and Southern Ocean will become undersaturated with respect to biogenic carbonate minerals is challenging in part due to the lack of baseline high-resolution carbon system data. Here we present $\sim 1700$ surface total alkalinity measurements from the Ross Sea and along a transect between the Ross Sea and southern Chile from the austral autumn (February-March 2013). We calculate the saturation state of aragonite $\left(\Omega_{\mathrm{Ar}}\right)$ and calcite $\left(\Omega_{\mathrm{Ca}}\right)$ using measured total alkalinity and $p \mathrm{CO}_{2}$. In the Ross Sea and south of the Polar Front, variability in carbonate saturation state $(\Omega)$ is mainly driven by algal photosynthesis. Freshwater dilution and calcification have minimal influence on $\Omega$ variability. We estimate an early spring surface water $\Omega_{\text {Ar }}$ value of $\sim 1.2$ for the Ross Sea using a total alkalinity-salinity relationship and historical $p \mathrm{CO}_{2}$ measurements. Our results suggest that the Ross Sea is not likely to become undersaturated with respect to aragonite until the year 2070 .
\end{abstract}

\section{Introduction}

Atmospheric $\mathrm{CO}_{2}$ concentrations have increased by $40 \%$ since preindustrial times to $\sim 400 \mathrm{ppm}$ today and could reach 936 ppm by the year 2100 (IPCC AR5 WG1, 2013). Due to oceanic uptake of $\mathrm{CO}_{2}$, surface ocean $\mathrm{pH}$ is already 0.1 units lower than preindustrial values and is projected to decrease by another 0.3-0.4 units by the end of the century, equivalent to a $50 \%$ decrease in carbonate ion $\left(\mathrm{CO}_{3}^{2-}\right)$ concentrations (Orr et al., 2005). Even after $\mathrm{CO}_{2}$ emissions are halted, it will take thousands of years before the surface ocean $\mathrm{pH}$ returns to preindustrial levels (Caldeira and Wickett, 2003; Archer et al., 2009).

The saturation state $(\Omega)$ of seawater with respect to a specific calcium carbonate $\left(\mathrm{CaCO}_{3}\right)$ mineral (aragonite, calcite, or magnesium calcite) is defined as

$\Omega=\frac{\left[\mathrm{Ca}^{2+}\right]\left[\mathrm{CO}_{3}^{2-}\right]}{K_{\mathrm{sp}}}$,

where $K_{\text {sp }}$ is the solubility product constant for the specific $\mathrm{CaCO}_{3}$ mineral and depends on salinity, temperature, and pressure (Mucci, 1983). Aragonite is $\sim 1.6$ times more soluble than calcite at $0{ }^{\circ} \mathrm{C}$ whereas the solubility of magnesium calcite varies depending on the mole fraction of magnesium ions (Dickson, 2010). $\Omega_{\text {Ar }}$ represents the saturation state of aragonite and $\Omega_{\mathrm{Ca}}$ represents the saturation state of calcite. $\Omega<1$ represents undersaturation where dissolution is thermodynamically favorable and $\Omega>1$ represents supersaturation where precipitation is favorable. Most surface waters of the global oceans are currently supersaturated with respect to $\mathrm{CaCO}_{3}$ (Feely et al., 2009). However, for some species including coccolithophorids, foraminifera, and tropical corals, decreasing $\mathrm{CO}_{3}^{2-}$ concentrations can decrease calcification rates even in supersaturated conditions (Riebesell et al., 2000; Moy et al, 2009; Andersson et al., 2011).

The Southern Ocean is especially vulnerable to ocean acidification (OA) due to its relatively low total alkalinity (TA) and because of increased $\mathrm{CO}_{2}$ solubility in cold water. In addition, Antarctic continental shelves have insignificant sedimentary $\mathrm{CaCO}_{3}$ to buffer against OA (Hauck et al., 2013). Modeling studies predict that surface waters in the Southern Ocean may start to become undersaturated with 
respect to aragonite by 2050 and be fully undersaturated by 2100 (Orr et al., 2005; Feely et al., 2009). McNeil and Matear (2008) have suggested that wintertime aragonite undersaturation in the Southern Ocean may begin as early as 2030.

OA-induced decreases in $\Omega$ have potentially serious consequences for Antarctic food webs. In the Ross Sea the aragonitic shelled pteropod Limacina helicina is a dominant zooplankton that can reach densities of 300 individuals $\mathrm{m}^{-3}$ (Hopkins, 1987; Seibel and Dierssen, 2003; Hunt et al., 2008). Pteropods are important prey for notothenioid fish, which in turn are major prey for penguins, seals, and whales (Foster and Montgomery, 1992; La Mesa et al., 2000, 2004). Pteropods may also be important contributors to the biological pump (Collier et al., 2000; Accornero et al, 2003; Manno et al., 2010). Orr et al. (2005) found that the shell of a subarctic pteropod started to dissolve within $48 \mathrm{~h}$ when placed in waters with the level of aragonite saturation expected to occur in the Southern Ocean by 2100 . Severe dissolution pitting was observed on live pteropods that were collected from the upper 200 meters in the Atlantic sector of the Southern Ocean, from waters that were near undersaturation with respect to aragonite (Bednaršek et al., 2012).

Other organisms in the Southern Ocean may be negatively impacted by OA include krill (Kawaguchi et al., 2013), foraminifera (Moy et al., 2009), sea urchins (Sewell and Hofmann, 2011), deep sea hydrocorals (Shadwick et al., 2014), sea stars (Gonzalez-Bernat et al., 2013), bivalves (Cummings et al., 2011), and brittle stars (McClintock et al., 2011). Conversely non-calcareous phytoplankton may benefit in the Ross Sea in a high $p \mathrm{CO}_{2}$ world, especially the larger diatom Chaetoceros lineola (Tortell et al., 2008; Feng et al., 2010).

There are only a few surface carbon system data sets from the Ross Sea (Bates et al, 1998; Sweeney et al., 2000b; Sandrini et al., 2007; Long et al., 2011; Mattsdotter Björk et al., 2014; Rivaro et al., 2014; Kapsenberg et al., 2015) that can be used to establish baselines in order to understand the relative importance of physical, chemical, and biological processes that drive the large spatial and seasonal variability of $\Omega$. With no winter $\Omega$ measurements, it is challenging to predict when the Ross Sea will become undersaturated with respect to aragonite and calcite. A model by McNeil et al. (2010) suggests that winter surface waters in the Ross Sea will become undersaturated with respect to aragonite by the year 2045 since sea ice, upwelling of deep water, and short residence times prevent these surface waters from reaching equilibrium with the atmosphere. However, McNeil et al. (2010) indirectly estimated surface winter $\Omega_{\mathrm{Ar}}$ values by using limited carbon system data from the spring (Sweeney et al., 2000b).

We present $\sim 1700$ underway TA measurements from the surface waters of the Ross Sea and along a transect across the Southern Ocean from the Ross Sea to southern Chile. By combining the underway TA measurements with $p \mathrm{CO}_{2}$ data we characterize the complete carbon system and describe patterns and controls on $\Omega$ variability. Finally, af- ter establishing a relationship between salinity and TA, we use the Lamont Doherty Earth Observatory (LDEO) $p \mathrm{CO}_{2}$ database (Takahashi et al., 2009) (available at http://www. ldeo.columbia.edu/res/pi/CO2) to provide an independent estimate of Ross Sea surface water $\Omega_{\mathrm{Ar}}$ in early spring.

\section{Study site}

The Antarctic Circumpolar Current (ACC) flows from east to west around the entire Antarctic continent and is composed of multiple fronts that separate distinct water masses (Rintoul et al., 2001). There are three primary fronts - the southern ACC front (SACCF), the Antarctic Polar Front (PF), and the Subantarctic Front (SAF) (Orsi et al., 1995). Sokolov and Rintoul (2009) found that these primary fronts are composed of multiple jets that they label south (S), middle (M), and north $(\mathrm{N})$. Convergent Ekman transport north of the westerly wind stress maximum (near the axis of the ACC) downwells surface water into the ocean interior. Circumpolar Deep Water (CDW) upwells south of the wind stress maximum where it becomes modified into Antarctic surface water (AASW) (Rintoul et al., 2001).

The cyclonic Ross Sea gyre is located south of the ACC (Smith et al., 2012). The southern portion of this gyre flows west along the Ross Sea continental slope and generates intrusions of CDW onto the Ross Shelf through the major troughs (Orsi et al., 2009; Dinniman et al., 2011; Kohut et al., 2013). In addition, AASW enters the Ross Sea in the east and flows westward along the Ross Ice Shelf (Orsi et al., 2009).

The Ross Sea is considered a biological hotspot supporting over 400 benthic species (Smith et al., 2012). During the winter the Ross Sea is mostly covered by sea ice, which begins to clear in November to form the largest polynya in Antarctica. There are two main phytoplankton blooms in the Ross Sea. The first bloom begins in late November in the Ross Sea polynya (Fig. 1a) and peaks in mid- to late December (Arrigo et al., 1999; Arrigo and van Dijken, 2004). In early January, sea ice melts in the western Ross Sea, lowering surface salinity and increasing stratification (Fig. 1b). As a result, a secondary diatom bloom forms in the west with productivity peaking in late January to early February (Arrigo et al., 1999; Arrigo and van Dijken, 2004) (Fig. 1c).

The Ross Sea phytoplankton blooms account for up to half of all primary production over the Antarctic continental shelf (Arrigo and McClain, 1994; Smith and Gordon, 1997; Arrigo and van Dijken, 2003). Photosynthesis reduces the concentration of nutrients and dissolved inorganic carbon (DIC) in the mixed layer, causing $\Omega$ to increase in surface waters (McNeil et al., 2010). Once the sea ice reforms during autumn and winter, remineralization of organic matter and deep convective mixing produces a relatively homogeneous water column, causing surface DIC concentrations to increase and $\Omega$ to decrease (Gordon et al., 2000; Sweeney et al., 2000b; Petty et al., 2014). 

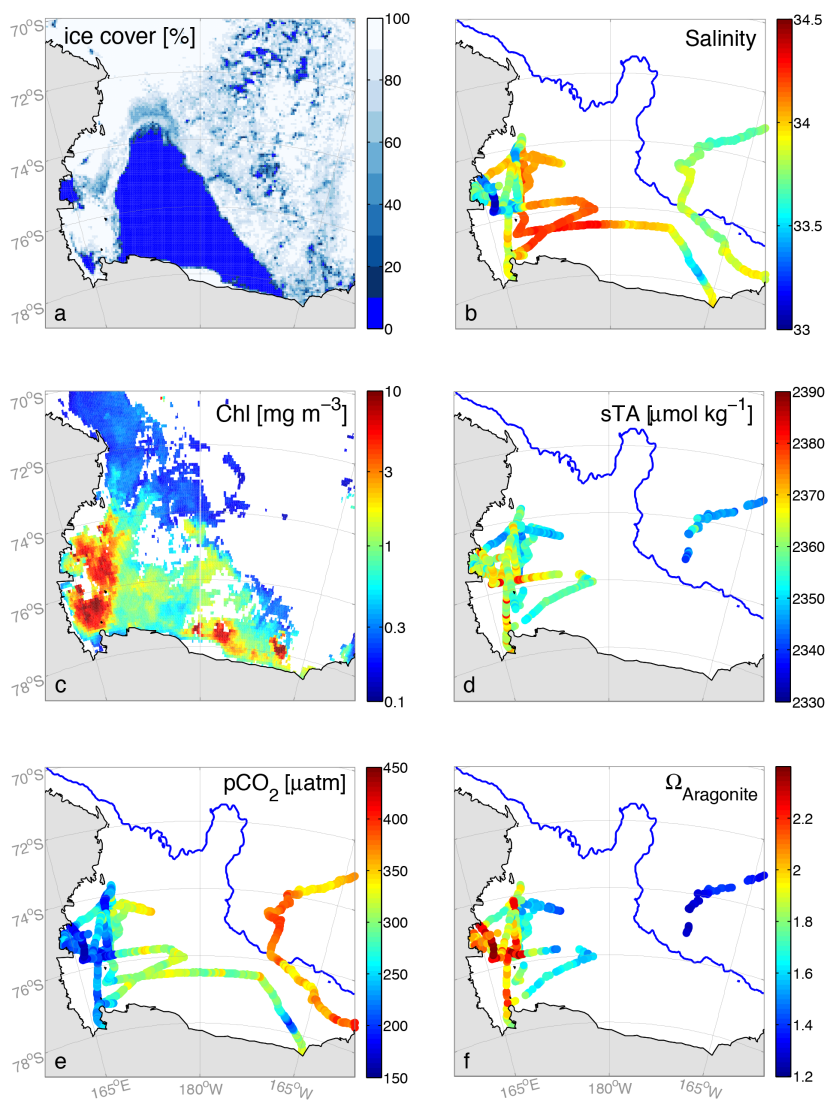

Figure 1. Maps of (a) $6.25 \mathrm{~km}$ gridded sea-ice concentration on 1 December 2012 from the University of Bremen, http://www.iup. uni-bremen.de:8084/amsr2/ (Spreen et al., 2008); (b) sea surface salinity from NBP 13-02; (c) satellite chlorophyll concentration on February 2013 from the $9 \mathrm{~km}$ Level 3 Aqua MODIS product, http://oceancolor.gsfc.nasa.gov/cgi/l3; (d) sTA from NBP 13-02; (e) $p \mathrm{CO}_{2}$ from NBP $13-02$; (f) aragonite saturation state $\left(\Omega_{\mathrm{Ar}}\right)$ from NBP 13-02.

\section{Methods}

\subsection{Analytical methods}

As part of the TRacing the fate of Algal Carbon Export in the Ross Sea (TRACERS) program, we undertook continuous measurements of surface water TA in the western Ross Sea aboard the Nathaniel B. Palmer (NBP13-02) from 13 February through 9 March 2013. In addition, from 19 March to 2 April 2013, we made continuous measurements of surface water TA in transit between the Ross Sea and southern Chile along the cruise track shown in Fig. 2. Underway TA measurements were conducted using the shipboard uncontaminated continuous flow system with an intake located at $\sim 5 \mathrm{~m}$ depth. Seawater from the ship's underway system was redirected to the bottom of a $250 \mathrm{~mL}$ free surface interface cup flowing at $2 \mathrm{~L} \mathrm{~min}^{-1}$ and was drawn from the bottom of the cup for TA analysis without filtration. The entire system
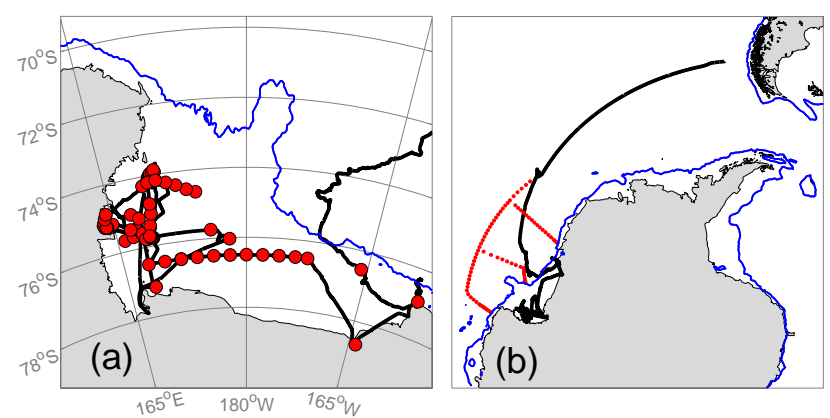

Figure 2. Cruise track (black line) from NBP 13-02. Stations used in this study (red circles) from (a) TRACERS (NBP 13-02) and (b) CLIVAR (NBP 11-02). Blue line is the $1000 \mathrm{~m}$ isobath.

was automated and relatively unattended. The sampling cycle was every 24 min on a custom-configured Metrohm 905 Titrando equipped with three Metrohm 800 Dosino syringe pumps (two $50 \mathrm{~mL}$ units for sample handling and rinsing and one $5 \mathrm{~mL}$ unit for acid titration). Temperature was measured at the cup and in the titration cell. We used certified $0.1 \mathrm{~N} \mathrm{HCl}$ provided by A. Dickson (Scripps Institution of Oceanography) for the potentiometric titrations and TA calculations follow Dickson et al. (2003). Since we consumed the certified $\mathrm{HCl}$ after $\sim 1000$ measurements in the Ross Sea, we have no TA data from the eastern Ross Sea. For the transect to southern Chile, we mixed our own $0.1 \mathrm{~N} \mathrm{HCl}$ solution (from $12.1 \mathrm{~N} \mathrm{HCl}$, laboratory grade $\mathrm{NaCl}$, and deionized water). We calibrated TA measurements using certified reference materials (CRMs) Batch 122 provided by A. Dickson (Scripps Institution of Oceanography). Our estimated precision for the underway TA measurements from $68 \mathrm{CRM}$ analyses is $\pm 3 \mu \mathrm{mol} \mathrm{kg}{ }^{-1}$ ( $\left.\pm 1 \mathrm{SD}\right)$.

Outlier TA analyses were identified by taking a running mean and standard deviation of nine consecutive measurements. A measurement was rejected if (1) the difference between the measurement and mean was greater than twice the standard deviation and (2) the difference between the measurement and mean was greater than $6 \mu \mathrm{mol} \mathrm{kg}-1$. A total of 65 measurements (out of 1716) were rejected.

We collected seawater samples for particulate organic carbon (POC) every $2 \mathrm{~h}$ from the ship's continuous flow system between the Ross Sea and Chile. Following the protocols of Knap et al. (1996), we filtered 1 to $3 \mathrm{~L}$ of seawater through precombusted Whatman GFC filters and immediately rinsed these filters with $10 \mathrm{~mL}$ of $0.01 \mathrm{~N} \mathrm{HCl}$ to remove carbonate. We air-dried the filters before sending them to Stanford University where they were analyzed on a Carlo Erba NA1500 Series 2 elemental analyzer.

Surface $p \mathrm{CO}_{2}$ measurements were made every 3 min using the LDEO air-sea equilibrator permanently installed on the NBP (data available at http://www.ldeo.columbia.edu/ $\mathrm{res} / \mathrm{pi} / \mathrm{CO} 2)$. The estimated precision is $\pm 1.5 \mu \mathrm{atm}$. 
Underway salinity and sea surface temperature (SST) were measured continuously by the ship's thermosalinograph (TSG) (Sea-Bird model SBE-45). These variables were binned into $1 \mathrm{~min}$ intervals.

We collected discrete water samples at 85 stations in the Ross Sea from 13 February through 18 March 2013 (Fig. 1a). We used a rosette sampler fitted with 24 Niskin bottles and a Sea-Bird model SBE-911+ conductivity, temperature, and depth sensor. We also measured salinity on discrete underway and hydrocast samples at $25^{\circ} \mathrm{C}$ using a Guildline 8400 Autosal four-electrode salinometer. The difference between the Autosal measurements and salinity from the conductivity sensor was less than 0.02 . In this paper we use the hydrocast samples to evaluate the controls of seasonal surface $\Omega_{\mathrm{Ar}}$ variability. The water column data will be further analyzed in upcoming papers.

We collected hydrocast samples for TA and DIC following the protocols of Dickson et al. (2007) and immediately added saturated mercuric chloride $(<0.1 \%$ by volume). For TA, we ran each sample within $12 \mathrm{~h}$ of collection using a second potentiometric titrator, a Metrohm 855 Robotic Titrosampler equipped with two 800 Metrohm Dosino syringe pumps (one $50 \mathrm{~mL}$ unit for rinsing and sample handling and one $5 \mathrm{~mL}$ unit for acid titration). The samples were prefiltered through $0.45 \mu \mathrm{m}$ polyvinylidene fluoride filters and the estimated precision based on the CRMs $(n=108)$ is $\pm 1.5 \mu \mathrm{mol} \mathrm{kg}-1$.

We measured DIC on hydrocast samples within $\sim 4 \mathrm{~h}$ of collection without filtration. We acidified $1.25 \mathrm{~mL}$ of the sample using a custom-built injection system coupled to an infrared gas analyzer (LI-COR LI7000). As described by Long et al. (2011), the infrared absorption signal versus time is integrated for each stripped gas sample to yield a total mass of $\mathrm{CO}_{2}$. Samples were run in triplicate or greater and were calibrated using CRMs between every 3-4 unknowns. Micro-bubbles regularly appeared within injected samples due to sample warming between acquisition and DIC analysis. Each integration curve was visually inspected and integration curves that exhibited evidence for bubbles were rejected. The estimated precision based upon unknowns (> 3500 runs) and CRM replicates $(n=855)$ for cruise NPB1302 is $\pm 3 \mu \mathrm{mol} \mathrm{kg}{ }^{-1}$.

\subsection{Carbon system calculations and crosschecks}

We calculate $\Omega$ and DIC (hereafter called DIC $_{\text {calc }}$ ) for underway samples with CO2SYS for MATLAB (Lewis and Wallace, 1998; van Heuven et al., 2011) with TA, $p \mathrm{CO}_{2}$, SST, and salinity as input variables. Calculations are only conducted for $p \mathrm{CO}_{2}$ measured within 3 min of the TA measurement $(n=1034)$, the average cycle time for the automated $p \mathrm{CO}_{2}$ measurements. We use the equilibrium constants of Mehrback et al. (1973) as refit by Dickson and Millero (1987) since previous studies have found that they are the optimal choice, including for Antarctic waters (Lee et al., 2000; Millero et al., 2002; McNeil et al., 2007). For the hydrocast data, we calculate $\Omega$ using TA, DIC, temperature, and salinity as input variables.

As a means of internal quality control, we use the initial $\mathrm{pH}$ reading from the TA titration as a third carbon system parameter to crosscheck the accuracy of our $\Omega_{\mathrm{Ar}}$ estimates. $\Omega_{\text {Ar }}$ calculated using TA and $p \mathrm{CO}_{2}$ is $0.02 \pm 0.07$ greater than $\Omega_{\mathrm{Ar}}$ calculated using TA and $\mathrm{pH}$. In addition, $\mathrm{DIC}_{\text {calc }}$ using TA and $p \mathrm{CO}_{2}$ is $2 \pm 7 \mu \mathrm{mol} \mathrm{kg}{ }^{-1}$ lower than $\mathrm{DIC}_{\text {calc }}$ using TA and $\mathrm{pH}$. Finally, measured $p \mathrm{CO}_{2}$ is $4 \pm 14 \mu \mathrm{atm}$ lower than $p \mathrm{CO}_{2}$ calculated from TA and $\mathrm{pH}$. These strong consistencies suggest that our $p \mathrm{CO}_{2}$ and TA measurements are accurate. Our surface TA and $\mathrm{DIC}_{\text {calc }}$ measurements versus latitude for the Southern Ocean are within the ranges of other studies (Metzl et al., 2006; McNeil et al., 2007; Mattsdotter Björk et al., 2014).

We compare the TA measurements from the surface hydrocasts $(<5 \mathrm{~m}$ deep) to the underway TA measurements made while the ship was still on station within $\sim 15$ min of when the surface samples were collected. The underway values are $3 \pm 5 \mu \mathrm{mol} \mathrm{kg}{ }^{-1}$ higher than the hydrocast TA values.

\subsection{Ross Sea and Southern Ocean calculations}

The $\Omega_{\mathrm{Ar}}$ of surface waters in the Ross Sea increases during the austral summer months (McNeil et al., 2010). We use DIC, TA, SST, and salinity to determine the controls on the seasonal cycle of surface water $\Omega_{\mathrm{Ar}}$. We normalize DIC and TA to a salinity of 34.5 , the average salinity of the Ross Sea (hereafter called sDIC and sTA). Due to the deep convective mixing during the winter, we use the average sDIC and sTA concentrations of hydrocast samples collected from 200 to $400 \mathrm{~m}$ to determine winter water values $\left(\mathrm{sDIC}=2221 \pm 5 \mu \mathrm{mol} \mathrm{kg} \mathrm{kg}^{-1}\right.$, sTA $=2338 \pm 3 \mu \mathrm{mol} \mathrm{kg}^{-1}$ ). While sDIC and sTA concentrations below $200 \mathrm{~m}$ are influenced by carbon export particularly in the summer and early autumn, observations show that SDIC and sTA concentrations are relatively uniform below $200 \mathrm{~m}$ across space and a given season (Table 1).

Following Hauri et al. (2013), the change in $\Omega_{\mathrm{Ar}}$ of surface hydrocast samples (upper $10 \mathrm{~m}$ ) from winter conditions can be expressed as

$$
\begin{aligned}
\Delta \Omega_{\mathrm{Ar}} & =\frac{\partial \Omega}{\partial \mathrm{DIC}} \Delta \mathrm{sDIC}+\frac{\partial \Omega}{\partial \mathrm{TA}} \Delta \mathrm{sTA} \\
& +\frac{\partial \Omega}{\partial T} \Delta T+\Delta S_{\Omega}+\text { Residuals },
\end{aligned}
$$

where

$\Delta S_{\Omega}=\frac{\partial \Omega}{\partial S} \Delta S+\frac{\partial \Omega}{\partial \mathrm{DIC}} \Delta \mathrm{DIC}^{s}+\frac{\partial \Omega}{\partial \mathrm{TA}} \Delta \mathrm{TA}^{s}$.

$\Delta$ sDIC and $\Delta$ sTA are the difference in SDIC and sTA for each sample from the winter value. The term $\Delta T$ is calculated using a winter SST of $-1.89^{\circ} \mathrm{C}$ (per Sweeney, 2003). $\Delta S_{\Omega}$ represents the total contribution of salinity changes to $\Delta \Omega_{\mathrm{Ar}}$. 
Table 1. Mean values for sDIC concentrations below $200 \mathrm{~m}$.

\begin{tabular}{lllll}
\hline Data source & Early spring & Spring & Summer & Autumn \\
\hline Sweeney et al. (2000) & $2226 \pm 3$ & $2233 \pm 3$ & $2237 \pm 3$ & $2233 \pm 5$ \\
Long et al. (2011) & & $2224 \pm 5$ & $2225 \pm 4$ & \\
This paper & & & & $2220 \pm 5$ \\
\hline
\end{tabular}

Since salinity between 200 and $400 \mathrm{~m}$ is variable across the Ross Sea (Orsi and Wiederwohl, 2009), $\Delta S$ is calculated as the difference between the salinity of a surface sample and the average salinity for samples from that station that are between 200 and $400 \mathrm{~m}$.

$\Delta \mathrm{DIC}^{s}$ and $\Delta \mathrm{TA}^{s}$ represent changes to DIC and TA due to dilution/concentration from freshwater input and sea-ice processes:

$$
\begin{aligned}
\Delta \mathrm{DIC}^{s}= & {\left[\mathrm{DIC}_{200-400} \cdot\left(\text { Salinity }_{\text {surface sample }} / \text { Salinity }_{200-400}\right)\right] } \\
& -\mathrm{DIC}_{200-400}, \\
\Delta \mathrm{TA}^{s}= & {\left[\mathrm{TA}_{200-400} \cdot\left(\text { Salinity }_{\text {surface sample }} / \text { Salinity }_{200-400}\right)\right] } \\
- & -\mathrm{TA}_{200-400} .
\end{aligned}
$$

$\mathrm{DIC}_{200-400}, \mathrm{TA}_{200-400}$, and Salinity $200-400$ are the average values for samples collected from 200 to $400 \mathrm{~m}$ calculated at each station.

The partial derivatives quantify the change in $\Omega_{\text {Ar }}$ per unit change in DIC, TA, temperature, and salinity. To determine the partial derivatives, we calculate $\Omega_{\mathrm{Ar}}$ for all hydrocast samples within the upper $10 \mathrm{~m}$ using DIC, TA, temperature, and salinity as input parameters. We recalculate $\Omega_{\mathrm{Ar}}$ after independently increasing DIC, TA, temperature, and salinity by one unit. The partial derivatives are the average difference between the initial $\Omega_{\mathrm{Ar}}$ and the recalculated $\Omega_{\mathrm{Ar}}$.

We use the same equations to evaluate the relative importance of DIC, TA, temperature, and salinity on the variability of $\Omega_{\mathrm{Ar}}$ from 75 to $55^{\circ} \mathrm{S}$. For the $\Delta$ terms, we calculate the change in sDIC, sTA, temperature, and salinity from the mean of the first six underway measurements at $75^{\circ} \mathrm{S}$. For Eqs. (4) and (5), instead of using DIC, TA, and salinity values from 200 to $400 \mathrm{~m}$, we use the mean of the first six underway measurements at $75^{\circ} \mathrm{S}$.

\section{Results and discussion}

\section{1 $\Omega$ in the Ross Sea}

Underway TA values range from 2268 to $2346 \mu \mathrm{mol} \mathrm{kg}-1$ $\left(\right.$ mean $\left.=2314 \pm 16 \mu \mathrm{mol} \mathrm{kg}^{-1}\right)$. Since TA strongly covaries with salinity $\left(R^{2}=0.86\right.$, residual $\left.\pm 6 \mu \mathrm{mol} \mathrm{kg} \mathrm{g}^{-1}\right)$, the lowest TA values are located in the west where the salinity is lowest (Fig. 1b). Values of sTA range from 2336 to $2386 \mu \mathrm{mol} \mathrm{kg} \mathrm{kg}^{-1}$ (mean $=2360 \pm 7 \mu \mathrm{mol} \mathrm{kg}{ }^{-1}$ ) and are influenced by calcification/dissolution as well as phytoplankton photosynthesis since one unit of nitrate drawdown increases TA by one unit (Brewer and Goldman, 1978) (Fig. 1d).

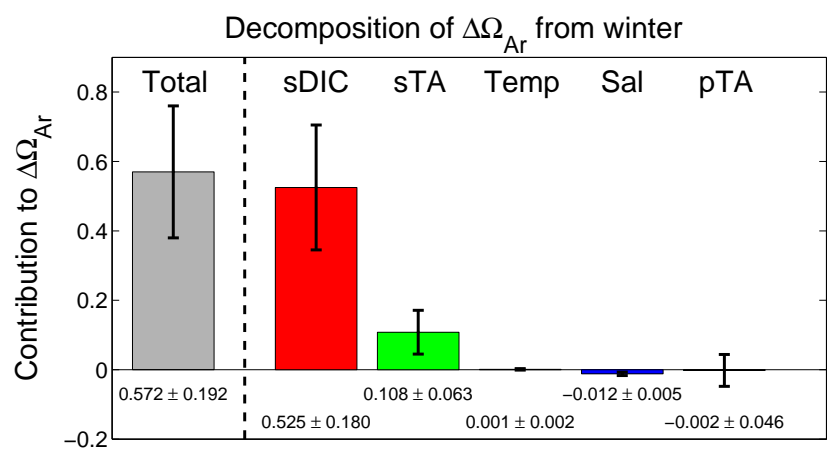

Figure 3. Contributions of sDIC, sTA, temperature, salinity, and PALK to changes in the aragonite saturation state $\left(\Omega_{\mathrm{Ar}}\right)$ of surface waters from the winter to early autumn. Error bars represent \pm 1 SD.

Surface $p \mathrm{CO}_{2}$ values range from 162 to $354 \mu$ atm and are lower in the west due to late-season phytoplankton photosynthesis (Fig. 1e). Surface $\Omega_{\mathrm{Ar}}$ ranges from 1.40 to 2.42 and $\Omega_{\mathrm{Ca}}$ ranges from 2.24 to 3.89 (Fig. 2f). The highest $\Omega_{\mathrm{Ar}}$ values are also located in the west. Phytoplankton photosynthesis increases $\Omega$ by both decreasing DIC and increasing TA.

Spatial and temporal variations in surface water $\Omega_{\mathrm{Ar}}$ are mainly controlled by sDIC in the Ross Sea (Eq. (2), Fig. 3). The concentration of sDIC decreased by $58 \pm 20 \mu \mathrm{mol} \mathrm{kg}-1$ from a winter value, causing $\Omega_{\mathrm{Ar}}$ to increase by $0.5 \pm 0.2$. In addition, sTA increased by $11 \pm 7 \mu \mathrm{mol} \mathrm{kg}^{-1}$ during the preceding summer months, causing $\Omega_{\mathrm{Ar}}$ to increase by $0.1 \pm 0.1$. Although there was a significant reduction in salinity compared to winter values $(0.7 \pm 0.3), \Omega_{\mathrm{Ar}}$ only decreased by $\sim 0.01$ due to this freshening since both DIC and TA concentrations were reduced. Lastly, the effect of temperature on $\Omega_{\mathrm{Ar}}$ was negligible since the Ross Sea only experiences a $2{ }^{\circ} \mathrm{C}$ seasonal change in SSTs (Sweeney, 2003).

Two processes can reduce sDIC, calcification, and phytoplankton photosynthesis. To evaluate the importance of calcification, we use time-dependent changes in potential alkalinity (PALK $=$ sNitrate + sTA) from a winter value $\left(2367 \pm 3 \mu \mathrm{mol} \mathrm{kg}^{-1}\right.$, defined as average value for all samples between 200 and $400 \mathrm{~m}$ ). While TA will increase during photosynthesis due to nitrate drawdown, PALK will be conserved. Therefore, changes in PALK can be attributed to calcification and dissolution. The average $\triangle$ PALK from a winter concentration is negligible $\left(0 \pm 5 \mu \mathrm{mol} \mathrm{kg}{ }^{-1}\right)$; therefore, calcification appears to be insignificant and the increase in sTA from winter conditions is largely driven by nitrate drawdown during photosynthesis. Earlier studies found that calcification contributed to only $\sim 5 \%$ of the total seasonal DIC drawdown (Bates et al., 1998; Sweeney et al., 2000a). Therefore, we argue that photosynthesis exerts the dominant control on sDIC, sTA, and $\Omega_{\mathrm{Ar}}$. While the highest $\Omega_{\mathrm{Ar}}$ value that we observed was 2.4 , values up to $\sim 4$ have been observed during December-January (McNeil et al., 2010). By 


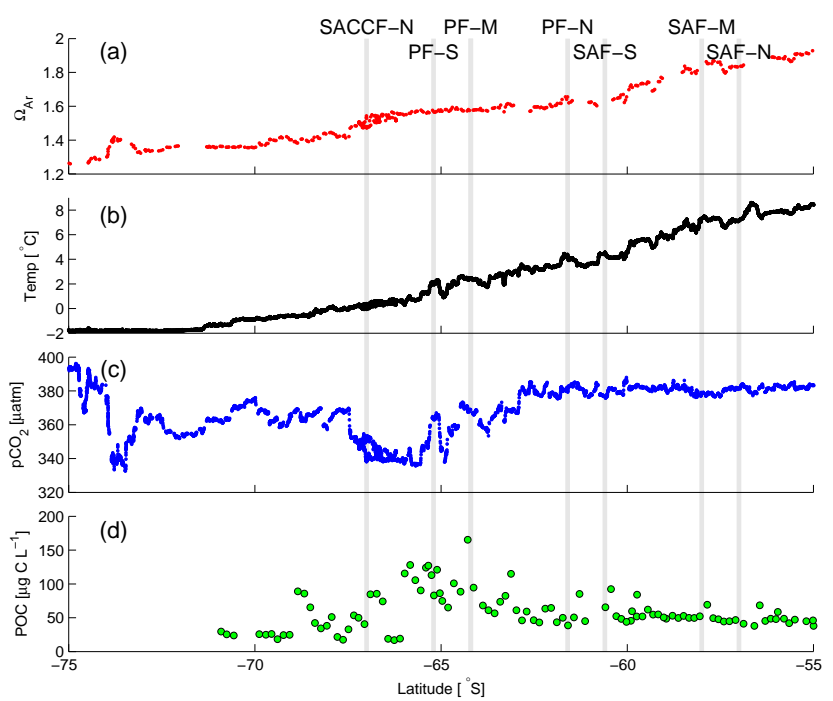

Figure 4. Surface water properties from a Southern Ocean transect, 20 March-2 April 2013: (a) aragonite saturation state $\left(\Omega_{\mathrm{Ar}}\right)$, (b) SST, (c) $p \mathrm{CO}_{2}$, and (d) particulate organic carbon. The locations of the Subantarctic Front (SAF), the Polar Front (PF), and the southern Antarctic Circumpolar Current Front (SACCF) from Sokolov and Rintoul (2009) are indicated (gray lines).

the time we arrived in the Ross Sea, surface sDIC concentrations would have already increased relative to the summer due to enhanced air-sea $\mathrm{CO}_{2}$ fluxes (Arrigo and van Dijken, 2007), deepening of the mixed layer (Sweeney, 2003), and remineralization of organic carbon (Sweeney et al., 2000b).

Mattsdotter Björk et al. (2014) also argue that phytoplankton photosynthesis is the major control on surface water $\Omega_{\mathrm{Ar}}$ variability between the Ross Sea and the Antarctic Peninsula based upon the covariance of $\Omega_{\mathrm{Ar}}$ and chlorophyll $a$. The largest contributor to seasonal $\Omega_{\mathrm{Ar}}$ change in the Chukchi Sea in the Arctic is also phytoplankton photosynthesis (Bates et al., 2013). However, unlike the Ross Sea, numerous studies have also demonstrated aragonite undersaturation of surface waters in parts of the Arctic due to sea-ice melt and river runoff (Chierici and Fransson, 2009; Yamamoto-Kawai et al., 2009; Robbins et al., 2013).

\section{2 $\Omega$ in the Southern Ocean}

The spatial changes in $\Omega_{\mathrm{Ar}}$, SST, $p \mathrm{CO}_{2}$, and POC between 75 and $55^{\circ} \mathrm{S}$ are shown in Fig. 4. We also include the mean location of the fronts from Sokolov and Rintoul (2009) as they intersect our cruise track. The lowest $\Omega_{\mathrm{Ar}}$ value is 1.25 $\left(\Omega_{\mathrm{Ca}}=2.00\right)$ at $75^{\circ} \mathrm{S}$, corresponding with the highest $p \mathrm{CO}_{2}$ of $\sim 396 \mu \mathrm{atm}$. $\Omega_{\mathrm{Ar}}$ increases along the transect to reach a maximum of $1.93\left(\Omega_{\mathrm{Ca}}=3.04\right)$ at $55^{\circ} \mathrm{S}$. The changes in $\Omega_{\mathrm{Ar}}$ are not always monotonic. In two regions changes in $\Omega_{\mathrm{Ar}}$ can be attributed to enhanced primary production. Between 74 and $73^{\circ} \mathrm{S}, \Omega_{\mathrm{Ar}}$ first increases and then decreases by $\sim 0.1$. This corresponds with a $40 \mu$ atm drop and then rise in $p \mathrm{CO}_{2}$.

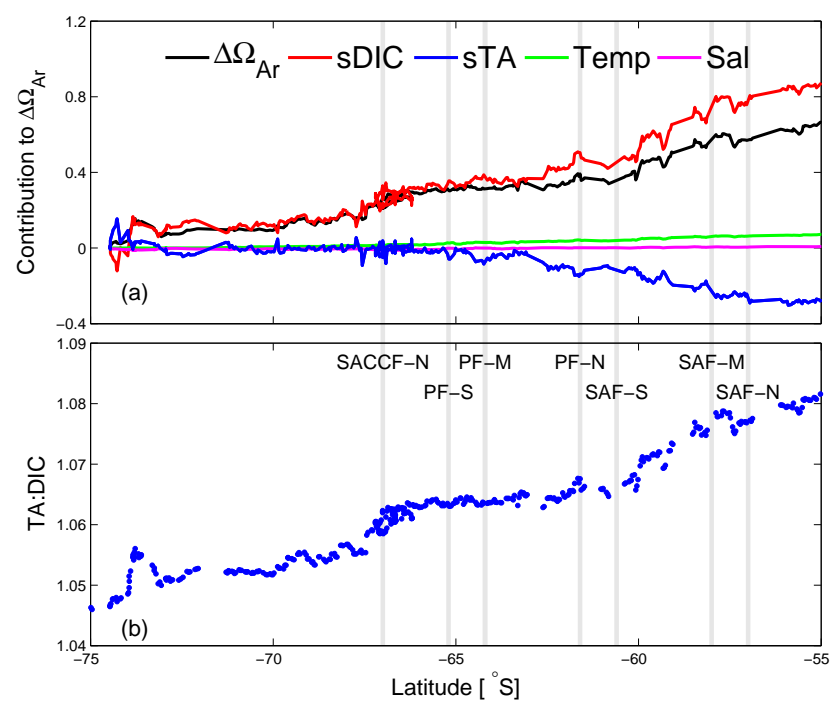

Figure 5. From surface water measurements along a Southern Ocean transect (a) contributions of changing sDIC (red), sTA (blue), temperature (green), and salinity (magenta) to changing aragonite saturation state (black, $\Omega_{\mathrm{Ar}}$ ) relative to the start of the transect and (b) TA to DIC ratios. The locations of the Subantarctic Front (SAF), the Polar Front (PF), and the southern Antarctic Circumpolar Current Front (SACCF) from Sokolov and Rintoul (2009) are indicated (gray lines).

Given that SST is constant, this localized increase in $\Omega_{\mathrm{Ar}}$ is likely due to phytoplankton photosynthesis. This region may be along the Antarctic Slope Front that is known for higher biological activity (Jacobs, 1991). There is another step in $\Omega_{\mathrm{Ar}}$ from $\sim 1.4$ to $\sim 1.55$ between 68 and $66^{\circ} \mathrm{S}$ across the SACCF-N. This step also corresponds with a decrease in $p \mathrm{CO}_{2}$ from $\sim 370$ to $\sim 340 \mu \mathrm{atm}$. Elevated POC concentrations between the SACCF-N and the PF-M correspond with these lower $p \mathrm{CO}_{2}$ values and again indicate enhanced phytoplankton photosynthesis. Rubin (2003) also found that $p \mathrm{CO}_{2}$ is reduced south of the $\mathrm{PF}\left(170^{\circ} \mathrm{W}\right)$ due to primary production.

To further gain insight into why $\Omega_{\mathrm{Ar}}$ increases along our transect, we quantify the contribution of changing sDIC (calculated from TA and $p \mathrm{CO}_{2}$ ), sTA, SST, and salinity to changing $\Omega_{\text {Ar }}$ (Fig. 5a). The dominant control is declining $\mathrm{sDIC}_{\text {calc }}$ from $\sim 2240$ to $\sim 2140 \mu \mathrm{mol} \mathrm{kg}{ }^{-1}$ between 75 and $55^{\circ} \mathrm{S}$, which causes $\Omega_{\mathrm{Ar}}$ to increase by 0.87 if sTA, SST, and salinity are held constant (Fig. 6). Declining sTA from $\sim 2340$ to $\sim 2310 \mu \mathrm{mol} \mathrm{kg}^{-1}$ partially counters the influence of SDIC $_{\text {calc }}$ and reduces $\Omega_{\text {Ar }}$ by 0.28 . The influences of SST and salinity on $\Omega_{\mathrm{Ar}}$ are minimal.

$\Omega_{\mathrm{Ar}}$ variability is driven almost entirely by changes in $\mathrm{sDIC}_{\text {calc }}$ from $75^{\circ} \mathrm{S}$ to the PF-S. Between the PF-S and the SAF-N, variability in $\Omega_{\mathrm{Ar}}$ is influenced by the opposing effects of $\mathrm{SDIC}_{\text {calc }}$ and sTA. The TA: $\mathrm{DIC}_{\text {calc }}$ ratio and $\Omega_{\mathrm{Ar}}$ are constant between the PF-S and the SAF-S since both $\mathrm{sDIC}_{\mathrm{calc}}$ and sTA decrease at the same rate (Fig. $5 \mathrm{~b}$ ). 


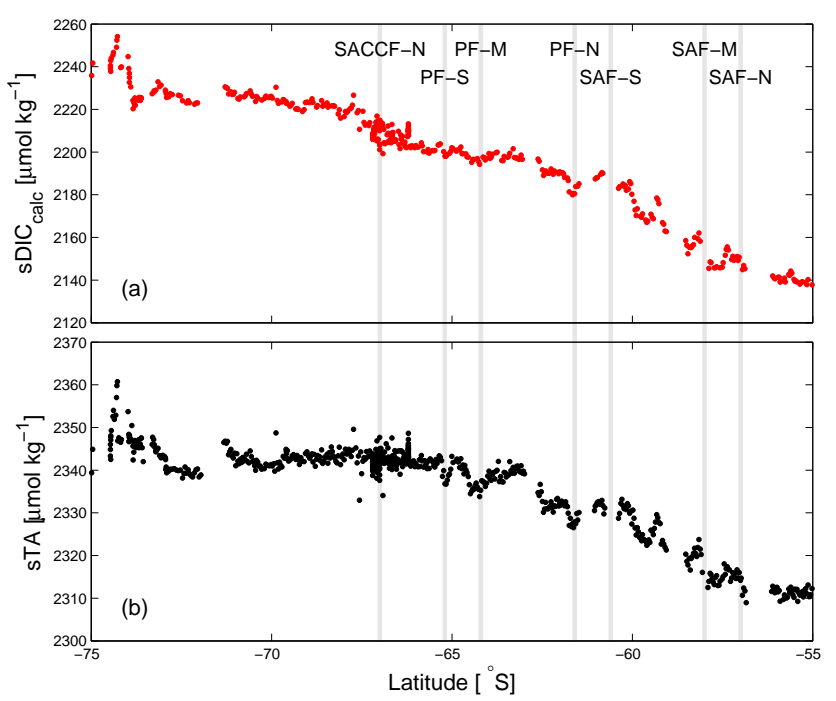

Figure 6. Measured surface water salinity normalized (a) DIC calculated from $p \mathrm{CO}_{2}$, TA, temperature, and salinity and (b) TA. The locations of the Subantarctic Front (SAF), the Polar Front (PF), and the southern Antarctic Circumpolar Current Front (SACCF) from Sokolov and Rintoul (2009) are indicated (gray lines).

Between the SAF-S and the SAF-N, $\Omega_{\text {Ar }}$ increases since $\mathrm{sDIC}_{\text {calc }}$ declines faster than sTA. North of the SAF-N, $\Omega_{\mathrm{Ar}}$ variability is again driven by $\mathrm{sDIC}_{\text {calc }}$. $\Omega_{\mathrm{Ar}}$ increases due to a decrease in $\mathrm{sDIC}_{\text {calc }}$ while sTA remains constant.

We examine possible controls on $\mathrm{SDIC}_{\text {calc }}$ along the transect. The concentration of $\mathrm{sDIC}_{\text {calc }}$ is highest south of the PF-S due to upwelling of CDW (Fig. 6a). To evaluate the properties of CDW, we use data from the 2011 Repeat Hydrography Cruise SO4P, which is part of the US Climate Variability and Predictability (CLIVAR) program (Swift and Orsi, 2012) (available at: http://www.clivar.org/ resources/data/hydrographic). We only use data from hydrocasts located between $168^{\circ} \mathrm{E}$ and $73^{\circ} \mathrm{W}$ where the bottom depth is $>1000 \mathrm{~m}$ (Fig. 2b). We reject the data from hydrocast 46(B) where the deep DIC data below $200 \mathrm{~m}$ are $\sim 30 \mu \mathrm{mol} \mathrm{kg}{ }^{-1}$ higher than the rest of the stations. Following Sweeney (2003), CDW is defined as centered on the level of maximum temperature below $150 \mathrm{~m}$.

From this CLIVAR data set, CDW has a SDIC value of $2243 \pm 3 \mu \mathrm{mol} \mathrm{kg}{ }^{-1}$. Between 75 and $74^{\circ} \mathrm{S}, \mathrm{sDIC}_{\text {calc }}$ concentration of surface water is also $2243 \pm 5 \mu \mathrm{mol} \mathrm{kg}{ }^{-1}$, indicating little modification to CDW and consistent with the observation that this region was covered by sea ice even during the summer of 2013 . At $74^{\circ} \mathrm{S}$ sDIC $\mathrm{Calc}_{\text {cal }}$ drops to $\sim 2220 \mu \mathrm{mol} \mathrm{kg}-1$ and by $66^{\circ} \mathrm{S}$, across the SACCF-N, $\mathrm{sDIC}_{\text {calc }}$ drops to $\sim 2200 \mu \mathrm{mol} \mathrm{kg}{ }^{-1}$. This $40 \mu \mathrm{mol} \mathrm{kg}^{-1}$ decrease in $\mathrm{SDIC}_{\text {calc }}$ between Antarctica and the PF-S is consistent with the observed drops in $p \mathrm{CO}_{2}$ that we attributed to photosynthesis. Rubin et al. (1998) also observed a 30$50 \mu \mathrm{mol} \mathrm{kg}{ }^{-1}$ decrease in sDIC at $67^{\circ} \mathrm{S}$ in Pacific Antarctic waters between winter and summer that they attribute to primary productivity.

sDIC $_{\text {calc }}$ continues to drop from $\sim 2220 \mu \mathrm{mol} \mathrm{kg}^{-1}$ at the PF-S to $\sim 2140 \mu \mathrm{mol} \mathrm{kg}{ }^{-1}$ at $55^{\circ} \mathrm{S}$, consistent with surface DIC measurements between 70 and $40^{\circ} \mathrm{S}$ compiled by McNeil et al. (2007). There are multiple factors likely responsible for this decrease in $\mathrm{sDIC}_{\text {calc. }}$. Both satellite (Arrigo et al., 2008) and in situ measurements (Reuer et al., 2007) show that annual primary productivity increases from south to north in the Southern Ocean. In addition, surface waters north of the PF advect northwards and accumulate a sDIC deficit. Finally, warmer water holds less DIC while in equilibrium with the atmosphere. There is little net air-sea $\mathrm{CO}_{2}$ flux between 75 and $55^{\circ} \mathrm{S}$ (except for net efflux at $60^{\circ} \mathrm{S}$ ) since warming and increased biological production compensate each other (Takahashi et al., 2012).

We also examine possible controls on sTA concentrations along the transect. The concentration of sTA is also highest south of the PF-S due to upwelling of CDW. Based off the CLIVAR data set, the sTA of CDW is $2334 \pm 3 \mu \mathrm{mol} \mathrm{kg}{ }^{-1}$. The sTA of surface water between $74^{\circ} \mathrm{S}$ and the PF-S is $\sim 2340 \mu \mathrm{mol} \mathrm{kg}{ }^{-1}$, slightly higher than its CDW source (Fig. 6b). Nitrate drawdown during photosynthesis may explain the elevated sTA. Between 75 and $74^{\circ}$ S, sTA exceeds $2360 \mu \mathrm{mol} \mathrm{kg}{ }^{-1}$. One possible explanation is that ikaite $\left(\mathrm{CaCO}_{3} \cdot 6 \mathrm{H}_{2} \mathrm{O}\right)$, a mineral that has been observed directly and indirectly to precipitate in Antarctic sea ice (Dieckmann et al., 2008; Fransson et al., 2011), dissolved into surface waters during the summer causing sTA concentrations to increase. Between the PF-S and SAF-N, sTA drops to $2310 \mu \mathrm{mol} \mathrm{kg}^{-1}$ where the concentrations level off. This drop appears to be in part due to the mixing of two end member water masses, AASW south of the PF-S and subantarctic surface water north of the SAF-N. The decreasing sTA is consistent with the suggestion of Millero et al. (1998) that a negative linear relationship between sTA and SST is due to colder water being indicative of greater upwelling of TA rich water.

This data set supports the argument that increased upwelling of CDW from strengthening westerly winds will increase OA in the Southern Ocean (Lenton et al., 2009). While the TA:DIC ratio for CDW is $1.040 \pm 0.002$, the $\mathrm{TA}$ : $\mathrm{DIC}_{\text {calc }}$ ratio for surface waters between $75^{\circ} \mathrm{S}$ and the PF-S ranges from 1.046 to 1.064 (Fig. 5b). Therefore increased upwelling will lower the TA:DIC ratio and cause $\Omega_{\text {Ar }}$ to decrease.

\subsection{Estimate of wintertime surface $\Omega_{\mathrm{Ar}}$ values in the Ross Sea}

Efforts to predict winter $\Omega_{\mathrm{Ar}}$ undersaturation in the Ross Sea are complicated by the complete lack of carbon system measurements from the winter months in the Ross Sea.

McNeil et al. (2010) estimated winter surface water $\Omega_{\mathrm{Ar}}$ by using the lowest observed $\Omega_{\mathrm{Ar}}$ value from early spring when the Ross Sea is still covered by sea ice. They used mid- 
October and early November carbon system measurements from the Joint Global Ocean Flux Study (JGOFS) (Sweeney et al., 2000b). Although sea-ice algae productivity peaks in November, its impact on water column DIC concentrations is likely to be negligible (Saenz and Arrigo, 2014). McNeil et al. (2010) found that early spring surface water $\Omega_{\mathrm{Ar}}$ was $\sim 1.2$. There was a single $\Omega_{\text {Ar }}$ value $<1.1$ that they used as an initial condition along with the IPCC US92a scenario to predict that surface waters of the Ross Sea could begin to experience seasonally undersaturated conditions with respect to aragonite as early as 2015 if full equilibrium with rising atmospheric $\mathrm{CO}_{2}$ is achieved. Based on a three-dimensional coupled ice, atmosphere, and ocean model (Arrigo et al., 2003, Tagliabue and Arrigo, 2005), McNeil et al. (2010) argued that only $35 \%$ of the atmospheric $\mathrm{CO}_{2}$ signal equilibrates with Ross Sea surface waters due to sea ice, upwelling of CDW, and short residence times, thereby delaying the onset of aragonite undersaturation until 2045. Decadal wintertime surface carbon system measurements do not exist to directly validate this disequilibrium assumption. In addition, McNeil et al. (2010) would inaccurately predict when the Ross Sea would become undersaturated with respect to aragonite if the minimum wintertime surface $\Omega_{\text {Ar }}$ value used was low due to measurement error.

To independently calculate $\Omega_{\mathrm{Ar}}$ from early spring surface waters, we use the LDEO $p \mathrm{CO}_{2}$ measurements from November 1994, 1997, 2005, and 2006 that are from the Ross Shelf (defined by the $1000 \mathrm{~m}$ isopleth) and are south of $74^{\circ} \mathrm{S}$ (Fig. 7a). The earliest $p \mathrm{CO}_{2}$ measurements are from 16 November 1994, 17 November 1997, 6 November 2005, and 13 November 2006 when much of the Ross Sea is still covered in sea ice. The earliest measurements from 2005/06 are more likely to represent winter conditions since they are from $74^{\circ} \mathrm{S}$ as the NBP entered the Ross Sea. Conversely, the earliest measurements from $1994 / 97$ are from the $76.5^{\circ} \mathrm{S}$ line, close to where the Ross Sea polynya opens up from.

We calculate wintertime TA in the Ross Sea by establishing a salinity-TA relationship using data from Bates et al. (1998), Sweeney et al. (2000b), and our own hydrocast TA measurements from the upper $10 \mathrm{~m}$ (Fig. A1 in the Appendix). Since one unit of nitrate drawdown increases TA by one unit, the TA measurements are adjusted to winter nitrate concentrations of $29 \mu \mathrm{mol} \mathrm{kg}{ }^{-1}$ (the mean nitrate concentration between 200 and $400 \mathrm{~m}$ from our cruise). The relationship between TA and salinity is consistent among these independent data sets and the standard deviation of the residuals for TA is $\pm 5 \mu \mathrm{mol} \mathrm{kg}^{-1}$.

We calculate historical $\Omega_{\mathrm{Ar}}$ using historical $p \mathrm{CO}_{2}$ measurements, salinity-derived TA, SST, and salinity. Phosphate and silicate are set to the winter values of 2.1 and $79 \mu \mathrm{mol} \mathrm{kg}{ }^{-1}$, respectively. The TSG salinity data from the historical $p \mathrm{CO}_{2}$ measurements appear reasonable and are uncalibrated. While the largest offset in TSG salinity compared with Autosal measurements is 0.3 , such error is not typical. To test the possible impact of a poor salinity calibration, we
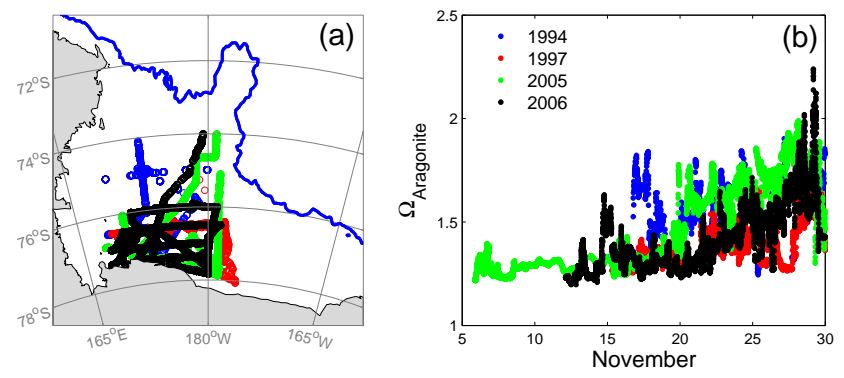

Figure 7. Estimating winter surface aragonite saturation states $\left(\Omega_{\mathrm{Ar}}\right)$ : (a) map of surface $p \mathrm{CO}_{2}$ measurements from the LDEO $p \mathrm{CO}_{2}$ database (http://www.ldeo.columbia.edu/res/pi/CO2) used in this study from November 1994 (blue), 1997 (red), 2005 (green), and 2006 (black). Blue line is the $1000 \mathrm{~m}$ isobath. (b) aragonite saturation state $\left(\Omega_{\mathrm{Ar}}\right)$ of surface waters from November calculated from $p \mathrm{CO}_{2}$, salinity-derived TA, temperature, and salinity.

recalculate $\Omega_{\mathrm{Ar}}$ for all $p \mathrm{CO}_{2}$ measurements after increasing salinity by 0.3 . TA calculated from the observed TA-salinity relationship increases by $\sim 21 \mu \mathrm{mol} \mathrm{kg}{ }^{-1}$ and $\Omega_{\mathrm{Ar}}$ increases by $0.024 \pm 0.003$.

The lowest $\Omega_{\text {Ar }}$ measurements are 1.24 in 1994, 1.25 in 1997, 1.22 in 2005, and 1.20 in 2006 (Fig. 7b). Although $\Omega_{\text {Ar }}$ declines from 1994 to 2006, we have low confidence in any trend due to spatial-temporal sampling biases. The lowest $\Omega_{\mathrm{Ar}}$ values are consistently between 1.2 and 1.3 as the ship crossed sea-ice-covered regions and open water that had experienced DIC drawdown. With the exception of a single measurement, the lowest 1996/97 $\Omega_{\mathrm{Ar}}$ values from McNeil et al. (2010) are also $\sim 1.2$. The similarity between the $\Omega_{\mathrm{Ar}}$ values reported by McNeil et al. (2010) from 1996/97 and our $2005 / 06$ values is consistent with their delayed acidification hypothesis.

A simple calculation also suggests that wintertime $\Omega_{\mathrm{Ar}}$ values may be closer to 1.2 than 1.1 . If salinity is 34.5 , approximately the mean salinity of the water column, TA would be $2339 \mu_{\mathrm{mol} \mathrm{kg}}^{-1}$ based on the observed TA-salinity linear relationship. Sweeney (2003) estimates winter $p \mathrm{CO}_{2}$ values of $\sim 425 \mu \mathrm{atm}$ based on deep $p \mathrm{CO}_{2}$ measurements made during early spring. Setting salinity to 34.5 , TA to $2339 \mu \mathrm{mol} \mathrm{kg}-1, p \mathrm{CO}_{2}$ to $425 \mu$ atm, temperature to -1.89 , silicate to $79 \mu \mathrm{mol} \mathrm{kg}{ }^{-1}$, and phosphate to $2.1 \mu \mathrm{mol} \mathrm{kg}-1$ yields a $\Omega_{\mathrm{Ar}}$ value of 1.22.

Although $p \mathrm{CO}_{2}$ measurements of surface waters colder than $-1.75^{\circ} \mathrm{C}$ south of $60^{\circ} \mathrm{S}$ typically reach $\sim 410 \mu$ atm by September, Takahashi et al. (2009) present a few measurements of $\sim 450 \mu \mathrm{atm}$. Even if $p \mathrm{CO}_{2}$ reaches $450 \mu \mathrm{atm}$ during winter in the Ross Sea, $\Omega_{\text {Ar }}$ would be 1.16 (with salinity at 34.5 and TA at $2339 \mu \mathrm{mol} \mathrm{kg}^{-1}$ ). In order to obtain $\Omega_{\mathrm{Ar}}$ of $1.1, p \mathrm{CO}_{2}$ would need to be $\sim 480 \mu$ atm, a value that appears unreasonably high given the available data sets from the Ross Sea. 
Table 2. Water properties of CDW from McNeil et al. (2010) and CLIVAR.

\begin{tabular}{lllllll}
\hline Data source & Salinity & DIC $\left(\mu \mathrm{mol} \mathrm{kg}^{-1}\right)$ & $\mathrm{TA}\left(\mu \mathrm{mol} \mathrm{kg}{ }^{-1}\right)$ & $\mathrm{PO}_{4}(\mu \mathrm{mol} \mathrm{kg}$ \\
& -1 & $\mathrm{SiO}_{4}(\mu \mathrm{mol} \mathrm{kg}$ & -1 & $\Omega_{\mathrm{Ar}}$ \\
\hline McNeil et al. (2010) & $34.70 \pm 0.02$ & $2255 \pm 1$ & 2330 & $2.22 \pm 0.01$ & $93.5 \pm 1.2$ & 1.01 \\
CLIVAR & $34.71 \pm 0.02$ & $2257 \pm 3$ & $2348 \pm 4$ & $2.21 \pm 0.04$ & $95.6 \pm 6.0$ & 1.18 \\
\hline
\end{tabular}

McNeil et al. (2010) calculated the $\Omega_{\mathrm{Ar}}$ of water arriving onto the Ross Shelf following the recipes of Jacobs et al. (1985): $50 \%$ CDW, $25 \%$ Tmin water (minimum temperature in upper $100 \mathrm{~m}$ ), and $25 \%$ AASW. To calculate the $\Omega_{\mathrm{Ar}}$ of these three source water masses, they used hydrocast temperature, salinity, and DIC data collected during the austral winter of 1994 from north of the Ross Shelf as described in Sweeney (2003). They calculated that the average $\Omega_{\mathrm{Ar}}$ of incoming water would be 1.08 .

We independently calculate $\Omega_{\text {Ar }}$ of incoming water using the 2011 CLIVAR hydrocast data from north of the Ross Shelf between $168^{\circ} \mathrm{E}$ and $73^{\circ} \mathrm{W}$ as described earlier (Fig. 2b). The $\Omega_{\text {Ar }}$ of water in the upper $100 \mathrm{~m}$ (AASW and Tmin) from the CLIVAR data set is $1.36 \pm 0.13$ and the $\Omega_{\mathrm{Ar}}$ of CDW (maximum temperature below $150 \mathrm{~m}$ ) is $1.18 \pm 0.03$ (Fig. A2 in the Appendix). Even if $100 \%$ of the incoming water onto the Ross Shelf is CDW, the $\Omega_{\mathrm{Ar}}$ of this incoming water would be greater than 1.08 . While most properties of CDW are similar between the 2011 CLIVAR data and the 1994 data used by McNeil et al. (2010), the TA of CDW from the CLIVAR data set is $18 \mu \mathrm{mol} \mathrm{kg}{ }^{-1}$ higher (Table 2).

Another approach to estimate the $\Omega_{\mathrm{Ar}}$ of winter surface waters is to use the properties of water below $200 \mathrm{~m}$. For the TRACERS data, sTA below $200 \mathrm{~m}$ is $2338 \pm 2 \mu \mathrm{mol} \mathrm{kg}-1$. For the JGOFS autumn cruise (NBP 97-3) sTA below $200 \mathrm{~m}$ is $2339 \pm 2 \mu \mathrm{mol} \mathrm{kg}-1$. Using the CLIVAR data set, sTA of CDW from off the Ross Shelf is $2334 \pm 3 \mu \mathrm{mol} \mathrm{kg}{ }^{-1}$. This consistency between independent data sets suggests that we can accurately estimate winter TA in the Ross Sea.

The range in sDIC below $200 \mathrm{~m}$ is much greater than that for sTA (Table 2). The lowest value is $2220 \pm 5 \mu \mathrm{mol} \mathrm{kg}-1$ from our cruise and the highest is $2237 \pm 3 \mu \mathrm{mol} \mathrm{kg}^{-1}$ from the summer JGOFS cruise (NBP 97-01). This range in SDIC concentrations below $200 \mathrm{~m}$ is not surprising given that sDIC concentrations vary across the input water masses. In addition, sDIC concentrations below $200 \mathrm{~m}$ will be influenced by carbon export particularly in summer and early autumn and over multiple seasons' air-to-sea flux of $\mathrm{CO}_{2}$.

Assuming that deep water concentrations of TA and DIC are relatively unmodified following wintertime deep convective mixing, we estimate the $\Omega_{\mathrm{Ar}}$ of winter surface water by setting TA to $2338 \mu \mathrm{mol} \mathrm{kg}^{-1}$, salinity to 34.5 , temperature to $-1.89^{\circ} \mathrm{C}$, phosphate to $2.1 \mu \mathrm{mol} \mathrm{kg}{ }^{-1}$, and silicate to $79 \mu \mathrm{mol} \mathrm{kg}{ }^{-1}$. If DIC concentrations are $2220 \mu \mathrm{mol} \mathrm{kg}{ }^{-1}, \Omega_{\mathrm{Ar}}$ would be 1.37 . If sDIC concentrations are $2237 \mu \mathrm{mol} \mathrm{kg}^{-1}, \Omega_{\mathrm{Ar}}$ would be 1.24 and $p \mathrm{CO}_{2}$ would be $417 \mu \mathrm{atm}$.
These results are consistent with a study by Matson et al. (2014) where early spring $\Omega_{\text {Ar }}$ at $20 \mathrm{~m}$ depth calculated using $\mathrm{pH}$ and salinity-derived TA was 1.2-1.3 from Hut Point (bottom depth $>200 \mathrm{~m}$ ) and Cape Evans (bottom depth $<30 \mathrm{~m}$ ) in McMurdo Sound. In Prydz Bay, the lowest measured winter surface $\Omega_{\mathrm{Ar}}$ values were also $\sim 1.2$ for both 1993-1995 (Gibson and Trull, 1999; McNeil et al., 2011) and 2010-2011 (Roden et al., 2013). Weeber et al. (2015) using hydrocast data estimated that the $\Omega_{\mathrm{Ar}}$ of winter water in the Weddell Sea was $\sim 1.3$. In the Mertz Polynya, the lowest $\Omega_{\text {Ar }}$ value at $100 \mathrm{~m}$ (below the mixed layer) was 1.2 (Shadwick et al., 2013). In Arthur Harbor on the western Antarctic Peninsula the lowest winter surface $\Omega_{\mathrm{Ar}}$ value was 1.31 (Schram et al., 2015).

A few studies find Antarctic winter $\Omega_{\mathrm{Ar}}$ values for surface water below 1.2. Hauri et al. (2015) used LDEO $p \mathrm{CO}_{2}$ measurements and predicted TA from salinity to estimate winter $\Omega_{\mathrm{Ar}}$ values of surface water in the western Antarctic Peninsula. They found that $20 \%$ of $\Omega_{\mathrm{Ar}}$ values were below 1.2 during the spring and winter, with a few winter values near undersaturation. It is not surprising that winter surface $\Omega_{\mathrm{Ar}}$ values are lower in the Antarctic Peninsula than the Ross Sea given less sea ice in the Peninsula. In another study, Kapsenberg et al. (2015) report $\Omega_{\mathrm{Ar}}$ at $18 \mathrm{~m}$ depth (bottom depth $<30 \mathrm{~m}$ ) at two coastal sites in McMurdo Sound, the Jetty, and Cape Evans, for December-May and November-June, respectively, using $\mathrm{pH}$ and salinity-derived TA as input variables. The lowest $\Omega_{\mathrm{Ar}}$ observations were from May at both sites and were 1.22 and 0.96 at the Jetty and Cape Evans. The maximum calculated $p \mathrm{CO}_{2}$ was 559 at Cape Evans. The low $\Omega_{\mathrm{Ar}}$ and high calculated $p \mathrm{CO}_{2}$ values measured by Kapsenberg et al. (2015) may represent differences between coastal and open ocean systems - there may be a coastal amplification signal when sinking organic matter hits a shallow bed. Another possibility is that their carbon system time series, particularly at Cape Evans, is inaccurate. After conditioning and calibrating their $\mathrm{pH}$ measurements using discrete water samples, for logistical reasons Kapsenberg et al. (2015) could not collect additional validation samples during deployment or measure multiple carbon system parameters for crosscheck. Although the SeaFET pH sensors that they used are generally stable, they can drift (Bresnahan et al., 2014). Kapsenberg et al. (2015) have no means to assess possible $\mathrm{pH}$ sensor drift.

Following McNeil et al. (2010) and a Representative Concentration Pathway (RCP8.5) scenario (Meinshausen et al., $2011)$, we use the lowest $\Omega_{\mathrm{Ar}}$ values from $2006\left(\Omega_{\mathrm{Ar}}=1.20\right.$, 
$p \mathrm{CO}_{2}=428 \mu \mathrm{atm}, \mathrm{TA}=2328 \mu \mathrm{mol} \mathrm{kg}{ }^{-1}$, salinity $=34.33$, $\mathrm{SST}=-1.87^{\circ} \mathrm{C}, \quad$ phosphate $=2.1 \mu \mathrm{mol} \mathrm{kg}{ }^{-1}, \quad$ silicate $=79 \mu \mathrm{mol} \mathrm{kg}{ }^{-1}$ ) to assess when the Ross Sea could become corrosive to aragonite. While shelf water salinity in the Ross Sea has declined by 0.03 decade $^{-1}$ from 1958 to 2008 (Jacobs and Giulivi, 2010), we show that such rates of change will have inconsequential effects on $\Omega_{\mathrm{Ar}}$. For equilibrium conditions, surface waters in the Ross Sea would become corrosive to aragonite by 2040 (2092 for calcite) when atmospheric $\mathrm{CO}_{2}$ concentrations exceed $485 \mathrm{ppm}$. In the disequilibrium scenario (McNeil et al., 2010), surface aragonite undersaturation state would occur by 2071 (2185 for calcite) when atmospheric $\mathrm{CO}_{2}$ concentrations exceed 677 ppm.

Mattsdotter Björk et al. (2014) also predicted the onset of summertime aragonite in the Ross Sea. Their lowest $\Omega_{A r}$ value was also $\sim 1.2$ and they estimated onset of undersaturation between 2026 and 2030 by increasing DIC by $10 \mu \mathrm{mol} \mathrm{kg}^{-1}$ per decade. This approach does not take into account air-sea $\mathrm{CO}_{2}$ disequilibrium. In contrast, Hauck et al. (2010) found that only $3-5 \mu \mathrm{mol} \mathrm{kg}{ }^{-1}$ of anthropogenic carbon accumulated per decade between 1992 and 2008 in shelf water of the Weddell Sea. In short, our analysis suggests that it may be possible to prevent future winter aragonite undersaturation of surface waters in the Ross Sea. For instance, $\mathrm{CO}_{2}$ concentrations never exceed $543 \mathrm{ppm}$ in the $\mathrm{CO}_{2}$ stabilization scenario RCP4.5 (Meinshausen et al., 2011).

If the Ross Sea experiences aragonite undersaturation during winter in the future, live pteropod shells would start dissolving, making them more vulnerable to predation and bacterial infection (Bednaršek et al., 2012, 2014). In particular, pteropod larvae develop during the winter/spring (Gannefors et al., 2005; Hunt et al., 2008) and their shells have been shown to completely dissolve within weeks of exposure to aragonite undersaturation (Comeau et al., 2010). Declines in pteropod populations may reduce carbon export (Manno et al., 2010) and could have dramatic ecological effects up the food web.

Antarctic deep sea hydrocorals may also decline or disappear at the onset of aragonite undersaturation (Shadwick et al., 2014). In addition, the shells of post-mortem bivalves and brachiopods show significant dissolution within 2 months of exposure to undersaturated conditions, although live organisms may be able to compensate for this dissolution (McClintock et al., 2009). For instance, Cummings et al. (2011) show that the Antarctic bivalve Laternula elliptica can increase calcification in undersaturated conditions. However, the associated energy costs may be difficult to maintain over the long term, especially for larvae. Stumpp et al. (2012) shows that while echinoid larvae can maintain calcification in high $p \mathrm{CO}_{2}$ treatments, increased energetic costs reduce growth rates and ultimately increase mortality. Larvae of the Antarctic sea urchin Sterechinus neumayeri and sea star Odontaster validus are smaller and exhibit abnormal development under elevated $p \mathrm{CO}_{2}$ treatments (Byrne et al., 2013; GonzalezBernat et al., 2013; Yu et al., 2013). In addition, the synergistic effects of warming and OA could impact echinoderm fertilization and embryo development (Ericson et al., 2012). Although it is not clear to what extent species may acclimatize or adapt (e.g., Suckling et al., 2015), the onset of aragonite undersaturation during winter months may have profound impacts on the Ross Sea ecosystem.

\section{Conclusions}

Our study demonstrates the possibility of setting up underway TA measurement systems. Although our system was relatively unattended, carbon system crosschecks and comparisons between hydrocast and underway data indicate that our measurements were accurate. Similar underway TA systems could be set up on scientific vessels and ships of opportunity in undersampled regions of the world's oceans.

We find that the seasonal increase in $\Omega_{\mathrm{Ar}}$ in the Ross Sea by early autumn is driven almost entirely by phytoplankton photosynthesis. In the Southern Ocean between the Ross Sea and Chile we find that $\Omega_{\mathrm{Ar}}$ also increases mainly due to declining $\mathrm{DIC}_{\text {calc }}$ although declining TA partially counters the influence of declining $\mathrm{DIC}_{\text {calc }}$. The influences of SST and salinity on $\Omega_{\mathrm{Ar}}$ are minimal in the Ross Sea and on our Southern Ocean transect.

We establish a salinity-TA relationship for the winter that is consistent across independent data sets. Using historical $p \mathrm{CO}_{2}$ measurements from early spring along with TA predicted from salinity, we argue that it is unlikely that the Ross Sea actually experienced winter surface $\Omega_{\mathrm{Ar}}$ values of $\sim 1.1$ during 1996 (as per McNeil et al., 2010) and that a $\Omega_{\mathrm{Ar}}$ value of $\sim 1.2$ may more accurately represent current winter conditions.

Since predictions are sensitive to current surface wintertime $\Omega_{\mathrm{Ar}}$ values as well as the extent of disequilibrium, highly accurate carbon system measurements from the winter are crucial. It is also essential to measure more than two carbon system parameters for crosscheck. For instance, $\mathrm{pH}$ and $p \mathrm{CO}_{2}$ sensors on moorings and floats could be used with TA predicted from salinity to calculate $\Omega$ during the winter.

Our analysis indicates that the Ross Sea will not experience aragonite undersaturation until the year 2070 following RCP8.5. In some $\mathrm{CO}_{2}$ stabilization scenarios, including RCP4.5 (Meinshausen et al., 2011), the Ross Sea may avoid becoming corrosive to aragonite. 


\section{Appendix A}

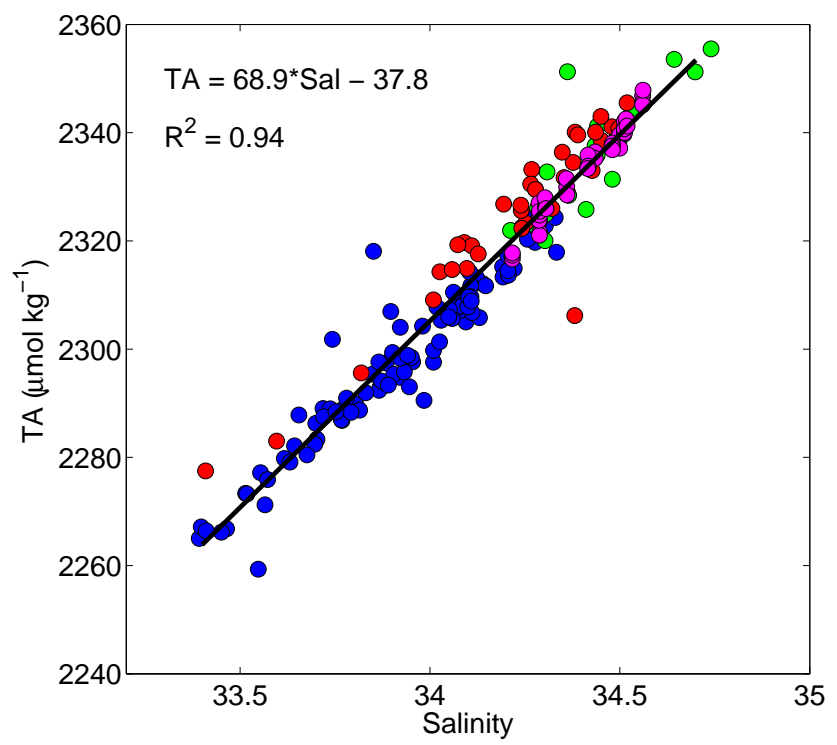

Figure A1. Linear regression between TA and salinity with surface data from February to March 2013 (blue; this study), November to December 1994 (green; Bates et al., 1998), December to January 1995/1996 (red; Bates et al., 1998), and April 1997 (magenta; Sweeney et al., 2000a). TA has been corrected to a nitrate concentration of $29 \mu \mathrm{mol} \mathrm{kg} \mathrm{g}^{-1}$ to account for the effects of nitrate drawdown on TA (Brewer and Goldman, 1976).

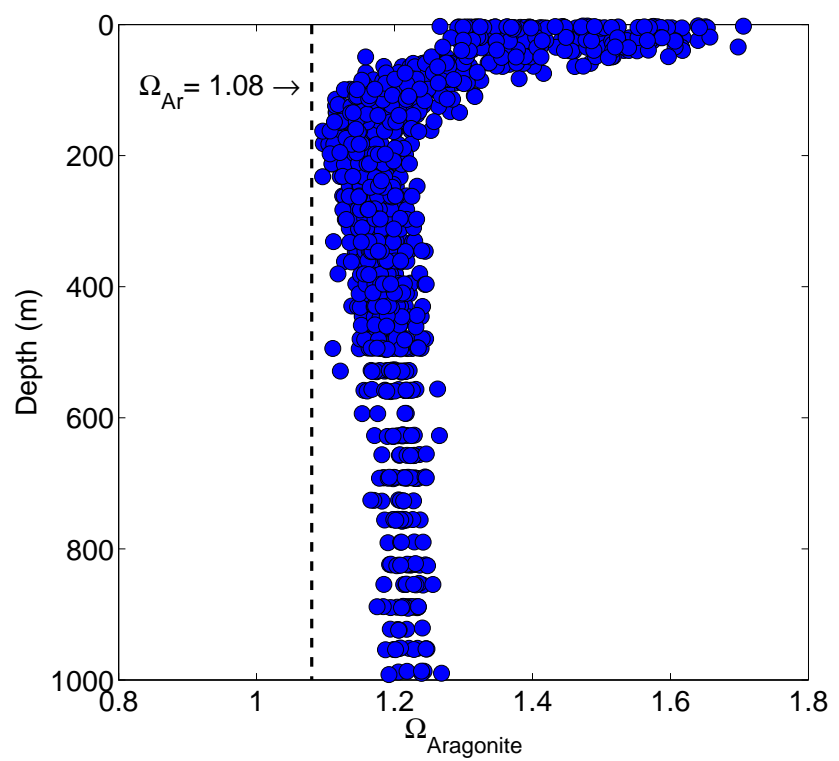

Figure A2. Profiles of aragonite saturation state $\left(\Omega_{\mathrm{Ar}}\right)$ from off the Ross Shelf (see Fig. 2b) from the CLIVAR program (NBP 11-02) calculated from TA, DIC, temperature, and salinity at surface pressures. 


\section{The Supplement related to this article is available online at doi:10.5194/bg-12-6881-2015-supplement.}

Acknowledgements. This work was supported by the US NSF (OPP-1142044 to R. B. Dunbar) and a NSF graduate research fellowship grant (DGE-114747 to H. B. DeJong). We thank the captain and crew of the R/V Nathaniel B. Palmer. We are grateful to $\mathrm{S}$. Bercovici for the nitrate data. The comments of two anonymous reviewers greatly improved this paper.

Edited by: L. Bopp

\section{References}

Accornero, A., Manno, C., Esposito, F., and Gambi, M. C.: The vertical flux of particulate matter in the polynya of Terra Nova Bay. Part II. Biological components, Antarct. Sci., 15, 175-188, doi:10.1017/S0954102003001214, 2003.

Andersson, A. J., Mackenzie, F. T., and Gattuso, J.-P.: Effects of ocean acidification on benthic processes, organisms, and ecosystems, in: Ocean Acidification, edited by: Gattuso, J.-P. and Hanson, L., Oxford University Press, New York, USA, 122-153, 2011.

Archer, D., Eby, M., Brovkin, V., Ridgwell, A., Cao, L., Mikolajewicz, U., Caldeira, K., Matsumoto, K., Munhoven, G., Montenegro, A., and Tokos, K.: Atmospheric Lifetime of Fossil Fuel Carbon Dioxide, Annu. Rev. Earth Pl. Sc., 37, 117-134, doi:10.1146/annurev.earth.031208.100206, 2009.

Arrigo, K. R. and McClain, C. R.: Spring Phytoplankton Production in the Western Ross Sea, Science, 266, 261-263, doi:10.1126/science.266.5183.261, 1994.

Arrigo, K. R. and van Dijken, G. L.: Phytoplankton dynamics within 37 Antarctic coastal polynya systems, J. Geophys. Res., 108, 3271, doi:10.1029/2002JC001739, 2003.

Arrigo, K. R. and van Dijken, G. L.: Annual changes in sea-ice, chlorophyll a, and primary production in the Ross Sea, Antarctica, Deep-Sea Res. Pt. II, 51, 117-138, doi:10.1016/j.dsr2.2003.04.003, 2004.

Arrigo, K. R. and van Dijken, G. L.: Interannual variation in airsea $\mathrm{CO}_{2}$ flux in the Ross Sea, Antarctica: A model analysis, J. Geophys. Res., 112, 1-16, doi:10.1029/2006JC003492, 2007.

Arrigo, K. R., Robinson, D. H., Worthen, D. L., Dunbar, R. B., DiTullio, G. R., VanWoert, M., and Lizotte, M. P.: Phytoplankton community structure and the drawdown of nutrients and $\mathrm{CO}_{2}$ in the Southern Ocean, Science, 283, 365-367, doi:10.1126/science.283.5400.365, 1999.

Arrigo, K. R., Worthen, D. L., and Robinson, D. H.: A coupled ocean-ecosystem model of the Ross Sea: 2. Iron regulation of phytoplankton taxonomic variability and primary production, J. Geophys. Res., 108, 3231, doi:10.1029/2001JC000856, 2003.

Arrigo, K. R., van Dijken, G. L., and Bushinsky, S.: Primary production in the Southern Ocean, 1997-2006, J. Geophys. Res., 113, C08004, doi:10.1029/2007JC004551, 2008.

Bates, N. R., Hansell, D. A., Carlson, C. A., and Gordon, L. I.: Distribution of $\mathrm{CO}_{2}$ species, estimates of net community production, and air-sea $\mathrm{CO}_{2}$ exchange in the Ross Sea polynya, J. Geophys. Res., 103, 2883-2896, doi:10.1029/97jc02473, 1998.
Bates, N. R., Orchowska, M. I., Garley, R., and Mathis, J. T.: Summertime calcium carbonate undersaturation in shelf waters of the western Arctic Ocean - how biological processes exacerbate the impact of ocean acidification, Biogeosciences, 10, 5281-5309, doi:10.5194/bg-10-5281-2013, 2013.

Bednaršek, N., Tarling, G. A., Bakker, D. C. E., Fielding, S., Jones, E. M., Venables, H. J., Ward, P., Kuzirian, A., Lézé, B., Feely, R. A., and Murphy, E. J.: Extensive dissolution of live pteropods in the Southern Ocean, Nat. Geosci., 5, 881-885, doi:10.1038/ngeo1635, 2012.

Bednaršek, N., Tarling, G. A., Bakker, D. C., Fielding, S., and Feely, R. A.: Dissolution dominating calcification process in polar pteropods close to the point of aragonite undersaturation, PLoS One, 9, e109183, doi:10.1371/journal.pone.0109183, 2014.

Bresnahan, P. J., Martz, T. R., Takeshita, Y., Johnson, K. S., and Lashomb, M.: Best practices for autonomous measurement of seawater $\mathrm{pH}$ with the Honeywell Durafet, Methods Oceanogr., 9, 1-33, doi:10.1016/j.mio.2014.08.003, 2014.

Brewer, P. G. and Goldman, J. C.: Alkalinity changes generated by phytoplankton growth, Limnol. Oceanogr., 21, 108-117, doi:10.4319/lo.1976.21.1.0108, 1976.

Byrne, M., Ho, M. A., Koleits, L., Price, C., King, C. K., Virtue, P., Tilbrook, B., and Lamare, M.: Vulnerability of the calcifying larval stage of the Antarctic sea urchin Sterechinus neumayeri to near-future ocean acidification and warming, Glob. Change Biol., 19, 2264-2275, doi:10.1111/gcb.12190, 2013.

Caldeira, K. and Wickett, M. E.: Oceanography: anthropogenic carbon and ocean pH, Nature, 425, p. 365, doi:10.1038/425365a, 2003.

Chierici, M. and Fransson, A.: Calcium carbonate saturation in the surface water of the Arctic Ocean: undersaturation in freshwater influenced shelves, Biogeosciences, 6, 2421-2431, doi:10.5194/bg-6-2421-2009, 2009.

Collier, R., Dymond, J., Honjo, S., Manganini, S., Francois, R., and Dunbar, R.: The vertical flux of biogenic and lithogenic material in the Ross Sea: Moored sediment trap observations 19961998, Deep-Sea Res. Pt. II, 47, 3491-3520, doi:10.1016/S09670645(00)00076-X, 2000.

Comeau, S., Gorsky, G., Alliouane, S., and Gattuso, J.-P.: Larvae of the pteropod Cavolinia inflexa exposed to aragonite undersaturation are viable but shell-less, Mar. Biol., 157, 2341-2345, doi:10.1007/s00227-010-1493-6, 2010.

Cummings, V., Hewitt, J., Van Rooyen, A., Currie, K., Beard, S., Thrush, S., Norkko, J., Barr, N., Heath, P., Halliday, N. J., Sedcole, R., Gomez, A., McGraw, C., and Metcalf, V.: Ocean acidification at high latitudes: potential effects on functioning of the Antarctic bivalve Laternula elliptica, PLoS ONE, 6, e16069, doi:10.1371/journal.pone.0016069, 2011.

Dickson, A. G.: The carbon dioxide system in seawater: equilibrium chemistry and measurements, in: Guide to Best Practices in Ocean Acidification Reseach and Data Reporting, edited by: Riebesell, U., Fabry, V. J., Hansson, L., and Gattuso, J.-P., Office for Official Publications of the European Communities, Luxembourg, 17-40, 2010.

Dickson, A. G. and Millero, F. J.: A comparison of the equilibrium constants for the dissociation of carbonic acid in seawater media, Deep-Sea Res., 34, 1733-1743, doi:10.1016/01980149(87)90021-5, 1987. 
Dickson, A. G., Afghan, J. D., and Anderson, G. C.: Reference materials for oceanic $\mathrm{CO} 2$ analysis: a method for the certification of total alkalinity, Mar. Chem., 80, 185-197, doi:10.1016/S03044203(02)00133-0, 2003.

Dickson, A. G., Sabine, C. L., and Christian, J. R.: Guide to best practices for ocean $\mathrm{CO}_{2}$ measurements, PICES Spec. Publ., 3, p. 191, doi:10.1159/000331784, 2007.

Dieckmann, G. S., Nehrke, G., Papadimitriou, S., Göttlicher, J., Steininger, R., Kennedy, H., Wolf-Gladrow, D., and Thomas, D. N.: Calcium carbonate as ikaite crystals in Antarctic sea ice, Geophys. Res. Lett., 35, 35-37, doi:10.1029/2008GL033540, 2008.

Dinniman, M. S., Klinck, J. M., and Smith, W. O.: A model study of Circumpolar Deep Water on the West Antarctic Peninsula and Ross Sea continental shelves, Deep-Sea Res. Pt. II, 58, 15081523, doi:10.1016/j.dsr2.2010.11.013, 2011.

Ericson, J. A., Ho, M. A., Miskelly, A., King, C. K., Virtue, P., Tilbrook, B., and Byrne, M.: Combined effects of two ocean change stressors, warming and acidification, on fertilization and early development of the Antarctic echinoid Sterechinus neumayeri, Polar Biol., 35, 1027-1034, doi:10.1007/s00300-0111150-7, 2012.

Feely, R., Doney, S., and Cooley, S.: Ocean Acidification: Present Conditions and Future Changes in a High- $\mathrm{CO}_{2}$ World, Oceanography, 22, 36-47, doi:10.5670/oceanog.2009.95, 2009.

Feng, Y., Hare, C. E., Rose, J. M., Handy, S. M., DiTullio, G. R., Lee, P. A., Smith, W. O., Peloquin, J., Tozzi, S., Sun, J., Zhang, Y., Dunbar, R. B., Long, M. C., Sohst, B., Lohan, M., and Hutchins, D. A.: Interactive effects of iron, irradiance and $\mathrm{CO}_{2}$ on Ross Sea phytoplankton, Deep-Sea Res. Pt. I, 57, 368-383, doi:10.1016/j.dsr.2009.10.013, 2010.

Foster, B. A. and Montgomery, J. C.: Planktivory in benthic nototheniid fish in McMurdo Sound, Antarctica, Environ. Biol. Fish., 36, 313-318, doi:10.1007/BF00001727, 1993.

Fransson, A., Chierici, M., Yager, P. L., and Smith, W. O.: Antarctic sea ice carbon dioxide system and controls, J. Geophys. Res., 116, C12035, doi:10.1029/2010JC006844, 2011.

Gannefors, C., Boer, M., Kattner, G., Graeve, M., Eiane, K., Gulliksen, B., Hop, H., and Falk-Petersen, S.: The Arctic sea butterfly Limacina helicina: lipids and life strategy, Mar. Biol., 147, 169177, doi:10.1007/s00227-004-1544-y, 2005.

Gibson, J. A. E. and Trull, T. W.: Annual cycle of fCO2 under seaice and in open water in Prydz Bay, East Antarctica, Mar. Chem., 66, 187-200, doi:10.1016/S0304-4203(99)00040-7, 1999.

Gonzalez-Bernat, M. J., Lamare, M., and Barker, M.: Effects of reduced seawater $\mathrm{pH}$ on fertilisation, embryogenesis and larval development in the Antarctic seastar Odontaster validus, Polar Biol., 36, 235-247, doi:10.1007/s00300-012-1255-7, 2013.

Gordon, L. I., Codispoti, L. A., Jennings J. C., J., Millero, F. J., Morrison, J. M., and Sweeney, C.: Seasonal evolution of hydrographic properties in the Ross Sea, Antarctica, 19961997, Deep-Sea Res. Pt. II, 47, 3095-3117, doi:10.1016/S09670645(00)00060-6, 2000.

Hauck, J., Hoppema, M., Bellerby, R. G. J., Völker, C., and WolfGladrow, D.: Data-based estimation of anthropogenic carbon and acidification in the Weddell Sea on a decadal timescale, J. Geophys. Res.-Oceans, 115, 1-14, doi:10.1029/2009JC005479, 2010.

Hauck, J., Arrigo, K. R., Hoppema, M., Van Dijken, G. L., Völker, C. and Wolf-Gladrow, D. A.: Insignificant buffering capacity of
Antarctic shelf carbonates, Global Biogeochem. Cy., 27, 11-20, doi:10.1029/2011GB004211, 2013.

Hauri, C., Gruber, N., Vogt, M., Doney, S. C., Feely, R. A., Lachkar, Z., Leinweber, A., McDonnell, A. M. P., Munnich, M., and Plattner, G.-K.: Spatiotemporal variability and long-term trends of ocean acidification in the California Current System, Biogeosciences, 10, 193-216, doi:10.5194/bg-10-193-2013, 2013.

Hauri, C., Doney, S. C., Takahashi, T., Erickson, M., Jiang, G., and Ducklow, H. W.: Two decades of inorganic carbon dynamics along the Western Antarctic Peninsula, Biogeosciences Discuss., 12, 6929-6969, doi:10.5194/bgd-12-6929-2015, 2015.

Hopkins, T. L.: Midwater food web in McMurdo Sound, Ross Sea, Antarctica, Mar. Biol., 96, 93-106, doi:10.1007/BF00394842, 1987.

Hunt, B. P. V, Pakhomov, E. A., Hosie, G. W., Siegel, V., Ward, P., and Bernard, K.: Pteropods in Southern Ocean ecosystems, Prog. Oceanogr., 78, 193-221, doi:10.1016/j.pocean.2008.06.001, 2008.

IPCC AR5 WG1, Climate Change 2013: The Physical Science Basis. Contribution of Working Group I to the Fifth Assessment Report of the Intergovernmental Panel on Climate Change Rep., Cambridge, UK and New York, NY, USA, 1535 pp., 2013.

Jacobs, S. S.: On the nature and significance of the Antarctic Slope Front, Mar. Chem., 35, 9-24, doi:10.1016/S03044203(09)90005-6, 1991.

Jacobs, S. S. and Giulivi, C. F.: Large multidecadal salinity trends near the Pacific-Antarctic continental margin, J. Climate, 23, 4508-4524, doi:10.1175/2010JCLI3284.1, 2010.

Jacobs, S. S., Fairbanks, R. G., and Horibe, Y.: Origin and evolution of water masses near the Antarctic continental margin: evidence from $\mathrm{H}_{2}^{18} \mathrm{O} / \mathrm{H}_{2}^{16} \mathrm{O}$ ratios in seawater, in: Oceanography of the Antarctic Continental Shelf, Antarctic Research Series, 43, edited by: Jacobs, S. S., American Geophysical Union, Washington, DC, USA, 59-85, 1985.

Kapsenberg, L., Kelley, A. L., Shaw, E. C., Martz, T. R., and Hofmann, G. E.: Near-shore Antarctic pH variability has implications for the design of ocean acidification experiments, Sci. Rep., 5, 9638, doi:10.1038/srep09638, 2015.

Kawaguchi, S., Ishida, A., King, R., Raymond, B., Waller, N., Constable, A., Nicol, S., Wakita, M., and Ishimatsu, A.: Risk maps for Antarctic krill under projected Southern Ocean acidification, Nat. Clim. Chang., 3, 843-847, doi:10.1038/nclimate1937, 2013.

Knap, A., Michaels A., Close A., Ducklow, H., and A. Dickson: Protocols for the Joint Global Ocean Flux Study (JGOFS) Core Measurements, JGOFS Rep., 19, 1-170, 1996.

Kohut, J., Hunter, E., and Huber, B.: Small-scale variability of the cross-shelf flow over the outer shelf of the Ross Sea, J. Geophys. Res.-Oceans, 118, 1863-1876, doi:10.1002/jgrc.20090, 2013.

La Mesa, M., Vacchi, M., and Zunini Sertorio, T.: Feeding plasticity of Trematomus newnesi (Pisces, Nototheniidae) in Terra Nova Bay, Ross Sea, in relation to environmental conditions, Polar Biol., 23, 38-45, doi:10.1007/s003000050006, 2000.

La Mesa, M., Eastman, J. T., and Vacchi, M.: The role of notothenioid fish in the food web of the Ross Sea shelf waters: A review, Polar Biol., 27, 321-338, doi:10.1007/s00300-004-0599-z, 2004.

Lee, K., Millero, F. J., Byrne, R. H., Feely, R. A., and Wanninkhof, R.: The recommended dissociation constants for carbonic acid in seawater, Geophys. Res. Lett., 27, 229-232, doi:10.1029/1999GL002345, 2000. 
Lenton, A., Codron, F., Bopp, L., Metzl, N., Cadule, P., Tagliabue, A., and Le Sommer, J.: Stratospheric ozone depletion reduces ocean carbon uptake and enhances ocean acidification, Geophys. Res. Lett., 36, L12606, doi:10.1029/2009GL038227, 2009.

Lewis, E. and Wallace, D. W. R.: Program Developed for $\mathrm{CO}_{2}$ System Calculations ORNL/CDIAC-105, Carbon Dioxide Information Analysis Centre, Oakridge National Laboratory, US Department of Energy, Oakridge, TN, USA, 1998.

Long, M. C., Dunbar, R. B., Tortell, P. D., Smith, W. O., Mucciarone, D. A., and Ditullio, G. R.: Vertical structure, seasonal drawdown, and net community production in the Ross Sea, Antarctica, J. Geophys. Res.-Oceans, 116, 1-19, doi:10.1029/2009JC005954, 2011.

Manno, C., Tirelli, V., Accornero, A., and Fonda Umani, S.: Importance of the contribution of limacina helicina faecal pellets to the carbon pump in terra nova bay (Antarctica), J. Plankton Res., 32, 145-152, doi:10.1093/plankt/fbp108, 2010.

Matson, P. G., Washburn, L., Martz, T. R., and Hofmann, G. E.: Abiotic versus Biotic Drivers of Ocean pH Variation under Fast Sea Ice in McMurdo Sound, Antarctica, 9, e107239, doi:10.1371/journal.pone.0107239, 2014.

Mattsdotter Björk, M., Fransson, A., Torstensson, A., and Chierici, M.: Ocean acidification state in western Antarctic surface waters: controls and interannual variability, Biogeosciences, 11, 57-73, doi:10.5194/bg-11-57-2014, 2014.

McClintock, J. B., Angus, R. A., Mcdonald, M. R., Amsler, C. D., Catledge, S. A., and Vohra, Y. K.: Rapid dissolution of shells of weakly calcified antarctic benthic macroorganisms indicates high vulnerability to ocean acidification, Antarct. Sci., 21, 449456, doi:10.1017/S0954102009990198, 2009.

McClintock, J. B., Amsler, M. O., Angus, R. A., Challener, R. C., Schram, J. B., Amsler, C. D., Mah, C. L., Cuce, J., and Baker, B. J.: The Mg-Calcite Composition of Antarctic Echinoderms: Important Implications for Predicting the Impacts of Ocean Acidification, J. Geol., 119, 457-466, doi:10.1086/660890, 2011.

McNeil, B. I. and Matear, R. J.: Southern Ocean acidification: a tipping point at 450-ppm atmospheric $\mathrm{CO}_{2}$, P. Natl. Acad. Sci. USA, 105, 18860-18864, doi:10.1073/pnas.0806318105, 2008.

McNeil, B. I., Metzl, N., Key, R. M., Matear, R. J., and Corbiere, A.: An empirical estimate of the Southern Ocean air-sea $\mathrm{CO}_{2}$ flux, Global Biogeochem. Cy., 21, GB3011, doi:10.1029/2007GB002991, 2007.

McNeil, B. I., Tagliabue, A., and Sweeney, C.: A multi-decadal delay in the onset of corrosive acidified waters in the Ross Sea of Antarctica due to strong air-sea $\mathrm{CO}_{2}$ disequilibrium, Geophys. Res. Lett., 37, 1-5, doi:10.1029/2010GL044597, 2010.

McNeil, B. I., Sweeney, C., and Gibson, J. A. E.: Short Note: Natural seasonal variability of aragonite saturation state within two Antarctic coastal ocean sites, Antarct. Sci., 23, 411-412, doi:10.1017/S0954102011000204, 2011.

Mehrback, C., Culberson, C. H., Hawley, J. E., and Pytkowicz, R. M.: Measurement of the apparent dissociation constants of carbonic acid in seawater at atmospheric pressure, Limnol. Oceanogr., 18, 897-907, doi:10.4319/lo.1973.18.6.0897, 1973.

Meinshausen, M., Smith, S. J., Calvin, K., Daniel, J. S., Kainuma, M. L. T., Lamarque, J., Matsumoto, K., Montzka, S. A., Raper, S. C. B., Riahi, K., Thomson, A., Velders, G. J. M. and van Vuuren, D. P. P.: The RCP greenhouse gas concentrations and their extensions from 1765 to 2300, Clim. Change, 109, 213241, doi:10.1007/s10584-011-0156-z, 2011.

Metzl, N., Brunet, C., Jabaud-Jan, A., Poisson, A., and Schauer, B.: Summer and winter air-sea $\mathrm{CO}_{2}$ fluxes in the Southern Ocean, Deep-Sea Res. Pt. I, 53, 1548-1563, doi:10.1016/j.dsr.2006.07.006, 2006.

Millero, F. J., Lee, K., and Roche, M.: Distribution of alkalinity in the surface waters of the major oceans, Mar. Chem., 60, 111-130, 1998.

Millero, F. J., Pierrot, D., Lee, K., Wanninkhof, R., Feely, R., Sabine, C. L., Key, R. M. and Takahashi, T.: Dissociation constants for carbonic acid determined from field measurements, Deep-Sea Res. Pt. I, 49, 1705-1723, doi:10.1016/S09670637(02)00093-6, 2002.

Moy, A. D., Howard, W. R., Bray, S. G., and Trull, T. W.: Reduced calcification in modern Southern Ocean planktonic foraminifera, Nat. Geosci., 2, 276-280, doi:10.1038/ngeo460, 2009.

Mucci, A.: The solubility of calcite and aragonite in seawater at various salinities, temperatures, and one atmosphere total pressure, Am. J. Sci., 283, 780-799, doi:10.2475/ajs.283.7.780, 1983.

Orr, J. C., Fabry, V. J., Aumont, O., Bopp, L., Doney, S. C., Feely, R. A., Gnanadesikan, A., Gruber, N., Ishida, A., Joos, F., Key, R. M., Lindsay, K., Maier-Reimer, E., Matear, R., Monfray, P., Mouchet, A., Najjar, R. G., Plattner, G.-K., Rodgers, K. B., Sabine, C. L., Sarmiento, J. L., Schlitzer, R., Slater, R. D., Totterdell, I. J., and Weirig, M.-F., Yamanaka, Y. and Yool, A.: Anthropogenic ocean acidification over the twenty-first century and its impact on calcifying organisms, Nature, 437, 681-686, doi:10.1038/nature04095, 2005 .

Orsi, A. H. and Wiederwohl, C. L.: A recount of Ross Sea waters, Deep-Sea Res. Pt. II, 56, 778-795, doi:10.1016/j.dsr2.2008.10.033, 2009.

Orsi, A. H., Whitworth, T., and Nowlin, W. D.: On the meridional extent and fronts of the Antarctic Circumpolar Current, DeepSea Res. Pt. I, 42, 641-673, doi:10.1016/0967-0637(95)00021W, 1995.

Petty, A. A., Holland, P. R., and Feltham, D. L.: Sea ice and the ocean mixed layer over the Antarctic shelf seas, The Cryosphere, 8, 761-783, doi:10.5194/tc-8-761-2014, 2014.

Reuer, M. K., Barnett, B. A., Bender, M. L., Falkowski, P. G., and Hendricks, M. B.: New estimates of Southern Ocean biological production rates from $\mathrm{O}_{2} / \mathrm{Ar}$ ratios and the triple isotope composition of $\mathrm{O}_{2}$, Deep-Sea Res. Pt. I, 54, 951-974, doi:10.1016/j.dsr.2007.02.007, 2007.

Riebesell, U., Zondervan, I., Rost, B., Tortell, P. D., Zeebe, R. E., and Morel, F. M.: Reduced calcification of marine plankton in response to increased atmospheric $\mathrm{CO}_{2}$, Nature, 407, 364-367, doi:10.1038/35030078, 2000.

Rintoul, S., Hughes, C., and Olbers, D.: The Antarctic Circumpolar Current System, in: Ocean Circulation and Climate, edited by: Siedler, G., Church, J., and Gould, J., Elsevier, New York, USA, 271-301, 2001.

Rivaro, P., Messa, R., Ianni, C., Magi, E., and Budillon, G.: Distribution of total alkalinity and $\mathrm{pH}$ in the Ross Sea (Antarctica) waters during austral summer 2008, Polar Res., 33, 20403, doi:10.3402/polar.v33.20403, 2014.

Robbins, L. L., Wynn, J. G., Lisle, J. T., Yates, K. K., Knorr, P. O., Byrne, R. H., Liu, X., Patsavas, M. C., Azetsu-Scott, K., and Takahashi, T.: Baseline monitoring of the western Arctic 
Ocean estimates $20 \%$ of Canadian basin surface waters are undersaturated with respect to aragonite., PLoS One, 8, e73796, doi:10.1371/journal.pone.0073796, 2013.

Roden, N. P., Shadwick, E. H., Tilbrook, B., and Trull, T. W.: Annual cycle of carbonate chemistry and decadal change in coastal Prydz Bay, East Antarctica, Mar. Chem., 155, 135-147, doi:10.1016/j.marchem.2013.06.006, 2013.

Rubin, S. I.: Carbon and nutrient cycling in the upper water column across the Polar Frontal Zone and Antarctic Circumpolar Current along $170^{\circ} \mathrm{W}$, Global Biogeochem. Cy., 17, 1087, doi:10.1029/2002GB001900, 2003.

Rubin, S. I., Takahashi, T., Chipman, D. W., and Goddard, J. G.: Primary productivity and nutrient utilization ratios in the pacific sector of the Southern Ocean based on seasonal changes in seawater chemistry, Deep-Sea Res. Pt. I, 45, 1211-1234, doi:10.1016/S0967-0637(98)00021-1, 1998.

Saenz, B. T. and Arrigo, K. R.: Annual primary production in Antarctic sea ice during 2005-2006 from a sea ice state estimate, J. Geophys. Res.-Oceans, 119, 3645-3678, doi:10.1002/2013JC009677, 2014.

Sandrini, S., Ait-Ameur, N., Rivaro, P., Massolo, S., Touratier, F., Tositti, L., and Goyet, C.: Anthropogenic carbon distribution in the Ross Sea, Antarctica, Antarct. Sci., 19, 395-407, doi:10.1017/S0954102007000405, 2007.

Schram, J. B., Schoenrock, K. M., McClintock, J. B., Amsler, C. D., and Angus, R. A.: Multi-frequency observations of seawater carbonate chemistry on the central coast of the western Antarctic Peninsula, Polar Res., 1, 1-49, 2015.

Seibel, B. A. and Dierssen, H. M.: Cascading Trophic Impacts of Reduced Biomass in the Ross Sea, Antarctica: Just the Tip of the Iceberg?, Biol. Bull., 205, 93-97, 2003.

Sewell, M. A. and Hofmann, G. E.: Antarctic echinoids and climate change: A major impact on the brooding forms, Glob. Change Biol., 17, 734-744, doi:10.1111/j.1365-2486.2010.02288.x, 2011.

Shadwick, E. H., Rintoul, S. R., Tilbrook, B., Williams, G. D., Young, N., Fraser, A. D., Marchant, H., Smith, J., and Tamura, T.: Glacier tongue calving reduced dense water formation and enhanced carbon uptake, Geophys. Res. Lett., 40, 904-909, doi:10.1002/grl.50178, 2013.

Shadwick, E. H., Tilbrook, B., and Williams, G. D.: Carbonate chemistry in the Mertz Polynya (East Antarctica): Biological and physical modification of dense water outflows and the export of anthropogenic $\mathrm{CO}_{2}$, J. Geophys. Res.-Oceans, 119, 1-14, doi:10.1002/2013JC009286, 2014.

Smith, W., Sedwick, P., Arrigo, K., Ainley, D., and Orsi, A.: The Ross Sea in a Sea of Change, Oceanography, 25, 90-103, doi:10.5670/oceanog.2012.80, 2012.

Smith, W. O. and Gordon, L. I.: Hyperproductivity of the Ross Sea (Antarctica) polynya during austral spring, Geophys. Res. Lett., 24, 233-236, doi:10.1029/96GL03926, 1997.

Sokolov, S. and Rintoul, S. R.: Circumpolar structure and distribution of the antarctic circumpolar current fronts: 1. Mean circumpolar paths, J. Geophys. Res.-Oceans, 114, 1-19, doi:10.1029/2008JC005108, 2009.

Spreen, G., Kaleschke, L., and Heygster, G.: Sea ice remote sensing using AMSR-E 89-GHz channels, J. Geophys. Res.-Oceans, 113, C02S03, doi:10.1029/2005JC003384, 2008.
Stumpp, M., Hu, M. Y., Melzner, F., Gutowska, M. A., Dorey, N., Himmerkus, N., Holtmann, W. C., Dupont, S. T., Thorndyke, M. C., and Bleich, M.: Acidified seawater impacts sea urchin larvae $\mathrm{pH}$ regulatory systems relevant for calcification., P. Natl. Acad. Sci. USA., 109, 18192-18197, doi:10.1073/pnas.1209174109, 2012.

Suckling, C. C., Clark, M. S., Richard, J., Morley, S. A., Thorne, M. S., Harper, E. M., and Peck, L. S.: Adult acclimation to combined temperature and $\mathrm{pH}$ stressors significantly enhances reproductive outcomes compared to short-term exposures, J. Anim. Ecol., 84, 773-784, doi:10.1111/1365-2656.12316, 2015.

Sweeney, C.: The Annual Cycle of Surface Water $\mathrm{CO}_{2}$ and $\mathrm{O}_{2}$ in the Ross Sea: A model for Gas Exchange on the Continental Shelves of Antarctica, in: Biogeochemistry of the Ross Sea, 295-310. 2003.

Sweeney, C., Hansell, D. A., Carlson, C. A., Codispoti, L. A., Gordon, L. I., Marra, J., Millero, F. J., Smith, W. O., and Takahashi, T.: Biogeochemical regimes, net community production and carbon export in the Ross Sea, Antarctica, Deep-Sea Res. Pt. II., 47, 3369-3394, doi:10.1016/S0967-0645(00)00072-2, 2000a.

Sweeney, C., Smith, W. O., Hales, B., Bidigare, R. R., Carlson, C. A., Codispoti, L. A., Gordon, L. I., Hansell, D. A., Millero, F. J., Park, M. O., and Takahashi, T.: Nutrient and carbon removal ratios and fluxes in the Ross Sea, Antarctica, Deep-Sea Res. Pt. II, 47, 3395-3421, doi:10.1016/S0967-0645(00)00073-4, 2000b.

Swift, J. H. and Orsi, A. H.: Sixty-four days of hydrography and storms: RVIB Nathaniel B. Palmer's 2011 SO4P Cruise, Oceanography, 25, 54-55, doi:10.5670/oceanog.2012.74, 2012.

Tagliabue, A. and Arrigo, K. R.: Iron in the Ross Sea: 1. Impact on $\mathrm{CO}_{2}$ fluxes via variation in phytoplankton functional group and non-Redfield stoichiometry, J. Geophys. Res.-Oceans, 110, 1-15, doi:10.1029/2004JC002531, 2005.

Takahashi, T., Sutherland, S. C., Wanninkhof, R., Sweeney, C., Feely, R. A., Chipman, D. W., Hales, B., Friederich, G., Chavez, F., Sabine, C., Watson, A., Bakker, D. C. E., Schuster, U., Metzl, N., Yoshikawa-Inoue, H., Ishii, M., Midorikawa, T., Nojiri, Y., Körtzinger, A., Steinhoff, T., Hoppema, M., Olafsson, J., Arnarson, T. S., Tilbrook, B., Johannessen, T., Olsen, A., Bellerby, R., Wong, C. S., Delille, B., Bates, N. R., and de Baar, H. J. W.: Climatological mean and decadal change in surface ocean $p \mathrm{CO}_{2}$, and net sea-air $\mathrm{CO}_{2}$ flux over the global oceans, Deep-Sea Res. Pt II, 56, 554-577, doi:10.1016/j.dsr2.2008.12.009, 2009.

Takahashi, T., Sweeney, C., Hales, B., Chipman, D., Newberger, T., Goddard, J., Iannuzzi, R., and Sutherland, S.: The Changing Carbon Cycle in the Southern Ocean, Oceanography, 25, 26-37, doi:10.5670/oceanog.2012.71, 2012.

Tortell, P. D., Payne, C. D., Li, Y., Trimborn, S., Rost, B., Smith, W. O., Riesselman, C., Dunbar, R. B., Sedwick, P., and DiTullio, G. R.: $\mathrm{CO}_{2}$ sensitivity of Southern Ocean phytoplankton, Geophys. Res. Lett., 35, L04605, doi:10.1029/2007GL032583, 2008.

van Heuven, S., Pierrot, D., Rae, J. W. B., Lewis, E., and Wallace, D. W. R.: MATLAB program developed for $\mathrm{CO}_{2}$ system calculations, ORNL/CDIAC-105b, Carbon Dioxide Information Analysis Center, Oak Ridge National Laboratory, US Department of Energy, Oak Ridge, TN, USA, availabe at: http://cdiac.ornl. gov/ftp/co2sys/CO2SYS_calc_MATLAB_v1.1/ (last access: 27 November 2015), 2011.

Weeber, A., Swart, S., and Monteiro, P. M. S.: Seasonality of sea ice controls interannual variability of summertime $\Omega_{\mathrm{A}}$ at 
the ice shelf in the Eastern Weddell Sea - an ocean acidification sensitivity study, Biogeosciences Discuss., 12, 1653-1687, doi:10.5194/bgd-12-1653-2015, 2015.

Yamamoto-Kawai, M., McLaughlin, F. A., Carmack, E. C., Nishino, S., and Shimada, K.: Aragonite undersaturation in the Arctic Ocean: effects of ocean acidification and sea ice melt, Science, 326, 1098-1100, doi:10.1126/science.1174190, 2009.
Yu, P. C., Sewell, M. A., Matson, P. G., Rivest, E. B., Kapsenberg, L., and Hofmann, G. E.: Growth attenuation with developmental schedule progression in embryos and early larvae of Sterechinus neumayeri raised under elevated CO2, PLoS One, 8, e52448, doi:10.1371/journal.pone.0052448, 2013. 